\title{
Güven, Saygınlık ve Karizma: Toplumsal İtibarın Kadim Dayanakları
}

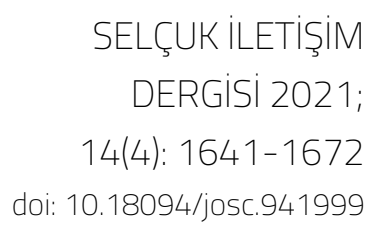

$[3]$

SEELRIK

ILETISIM

\section{Abdullah Koçak, İlhami Aydın}

\section{ÖZ}

Sosyal bilimler alanında yapılan çalışmalarda, itibar kavramına genel olarak markaların ya da kamusal yapıların imajını test etme maksadıyla başvurulmaktadır. Çalışmalar genelde, ekonomik döngü içinde artı değer yaratmanın önemli ve zorunlu bir bileşeni olarak markanın toplumsal imajına odaklanmaktadır. 'Toplum, sermaye yapılarına nasıl ve neden itibar atfeder?' ya da 'mevcut kurum/şirket itibarı nasıl zedelenir?' gibi artı değeri daha da mümkün hale getiren sorular ekseninde itibar çalışmaları yapılmaktadır. Ancak toplumsal etkileşimin önemli bir referans kodu olarak itibar, kadimden bu yana toplumsal aktörün prestijini tanımlamak için de kullanılır. Sosyal, kültürel, ekonomik, sembolik ve başka sermaye bileşenleri ekseninde inşa edilen itibar, kişiye toplumsal etkileşim mekanizması içinde ayrıcalıklı bir otorite kazandırır. İtibardan yansıyan otorite yapılarının toplumsal alandaki meşruiyeti sosyolojik olarak ifade edilmiştir. Çalışma, itibarın toplumsal alandaki boyutuna odaklanmıştır. Saha araştırmasından kotalı örneklemle elde edilen bulgular bağlamında anlam kazanan bu araştırma, itibarın genel görünümlerini betimlemiştir. İtibar kaynakları resmedilirken, temel değişkenlerle itibar arasında anlamlı bir ilişkinin varlı̆̆ı araştırılmıştır. Kuşak, cinsiyet, eğitim durumu değişkenleri, itibarı hangi kaynaklar bağlamında tanımladıkları irdelenmiştir. Ayrıca itibar tipolojileri sahip oldukları sermaye bileşenlerine göre gruplandırılmaları mümkün ise bu gruplandırmanın hangi kabuller üzerinden yapılabileceği de ifade edilmiştir. Elde edilen verilerden yola çıkarak itibara dair sonraki araştırmaların kapsamının ne olabileceğine dair tespitlere de yer verilmiştir.

Anahtar Sözcükler: İtibar, İtibar Kaynakları, Güven, Statü, Karizma

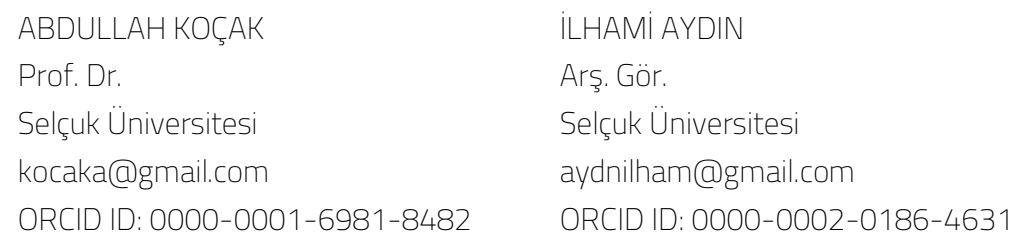

SELÇUK ILETIŞIM DERGISI 2021; 14(4): 1641-1672

doi: 10.18094/josc.941999

Geliş Tarihi: 24.05.2021 Kabul Tarihi: 06.09.2021 Yayın Tarihi: 25.10.2021 


\title{
Trust, Prestige and Charisma: Ancient Foundations of Social Reputation
}

\author{
JOURNAL OF SELÇUK \\ COMMUNICATION 2021; \\ 14(4): 1641-1672 \\ doi: $10.18094 /$ josc. 941999
}

\section{Abdullah Koçak, İlhami Aydın}

\begin{abstract}
In social scientific studies, the concept of reputation is generally applied to test the image of brands or public structures. Studies, in general, focuses on the social image of the brand as an important and obligatory component within economic cycle. Reputation studies are made around the questions such as 'How and why does the society accredits capital structures?' or 'How does the given institution/company reputation is bruised?', which make surplus value possible. However, reputation as an important reference code of social interaction have been used since ancient in order to define the prestige of social actor, too. Prestige, which is constructed around some capital components such as social, cultural, economic, symbolic and others, provides individual with a privileged authority within social interaction mechanism. The legitimacy of authority structures, in social sphere has been expressed sociologically. Study is focused on the dimension of reputation in social sphere. This work, which is meant within the context of the findings generated from a field research based on a quota sample, determined the general view of the reputation. The sources in which the variables of generation, gender, and educational status define reputation were examined. In addition, if it is possible to group reputation typologies according to their capital components, it is also stated on which assumptions this grouping can be made. Based on the data obtained, determinations regarding the scope of further studies on reputation have been given.
\end{abstract}

Keywords: Reputation, Reputation Sources, Trust, Status, Charisma

\author{
ABDULLAH KOÇAK \\ Prof. \\ ILHAMI AYDIN \\ Selçuk University \\ Res. Asst. \\ kocaka@gmail.com \\ Selçuk University \\ aydnilham@gmail.com \\ ORCID ID: 0000-0001-6981-8482 \\ ORCID ID: 0000-0002-0186-4631 \\ JOURNAL OF SELÇUK COMMUNICATION 2021; 14(4): 1641-1672 \\ doi: 10.18094/josc.941999
}




\section{Gíriş}

Kapitalist piyasa döngüsü içinde önemli bir yer edinmek veya piyasadaki kazanç payını sağlama almak için markalar arasında rekabete dayalı bir ilişki söz konusudur. Özellikle hedef kitlesini benzer argümanlarla ayartmaya çalışan ve dolayısıyla oluşan rekabet ilişkisinde üstün gelmenin arayışında olan sermaye yapıları, reklamlardan sosyal destek kampanyalarına, milli ve kutsal değerleri tüketmeye kadar farklı motivasyonlarla kendilerini kamuoyuna mal ederler. Kurumlar toplumsal algıyı belli argümanlarla manipüle etmeye çalışsa da sahada bir markaya güven ya da o markayı muadiline tercih etme konusu pek çok farklı ama tüketicinin lehine bileşenle test edilir (Smitds \& Riel, 2001, s. 1051-1062). Esasında toplum bu noktada aktif bir pozisyon takınmakta ve kendi çıkarını sağlayacak çeşitli stratejiler sergilemektedir. Fiyat, kalite, hijyen, ulaşılabilirlik, ideolojik saikler gibi tamamen toplumsal faydaya endeksli, onun beklentilerine cevap veren ayrıntılar güveni dolayısıyla itibarı olanaklı ve kullanışlı bir sermayeye dönüştürür.

Piyasa kurumları toplumsal güveni elde etmeye çalışırken verdikleri mücadeleden daha zoru ve belki bu mücadeleden daha önemlisi ise kazanılmış güvenin bir sermaye rezervi olarak kullanılması ve istikrarlı bir şekilde elde tutulmasıdır. Güveni var eden kaynaklardan biri işlevini yerine getirememesi durumu, uzun süre uğraş verilen ve kazanılan soyut sermayenin yani güven mevhumunun ve dolayısıyla itibarın bir anda tamamen yok olmasına yol açabilir (Karatepe S. , 2008, s. 84). Bu noktada şirketler kazanılmış güveni istikrarlı bir şekilde elde tutmak için toplumsal alanda güveni zedeleyecek açıkları kapatma veya yamalama uğraşı verirler. Bu uğraş, tercihten ziyade zorunlu bir tutumdur. Dolayısıyla ekonomik yapılar sadece somut sermaye birikimi ile güçlerini ispat etmezler. Belki de maddi sermayeden daha değerli olan ve bu sermaye stokuna daha fazla alan açan ise onlara duyulan güven yani onların itibarlarıdır. Bu bağlamda marka değerine, onun toplumsal alandaki itibarına ya da kredisine bakılarak karar verilir.

Kurumsal itibar konusunu topluma dönük basit ekonomik getirileri karşılayan bir değer olarak yorumlamamak gerekir. Geçmişe dönük olumlu veya olumsuz birikimin bir yansıması olarak değerlendirilebilir (Yarar, 2019). Her ne kadar topluma karşı ödev ve sorumlulukların yerine getirilmesi neticesinde elde edilen manevi bir kazanım olarak yorumlansa da esasında itibardan elde edilen prestij, farklı ilişki ağları içinde muhtemel getirilere de kapı aralar. Yüksek fiyat talebinin olumlu karşılanması, 
düşük faiz talebi, hedef kitlesine kolay ulaşmak, mali ve siyasal anlamda desteklenmek, paydaşlar arasında güven duyulmak gibi maddi ve manevi getiriler bunlardan birkaçıdır (Pira \& Sohodol, 2008, s. 143). Dolayısıyla itibar kavramı manevi bir sermaye rezervi olarak farklı pek çok maddi sermaye rezervlerinden daha işlevsel olarak yani değer yükü daha fazla olarak ifade edilebilir. İtibar kavramına bu minvalde sosyal bilimler alanında genelde kurumsal yapıların değerini ölçmek maksadıyla başvurulmaktadır. Kurumsal yönüne paralel olarak itibar, aynı zamanda toplumsal alanda en mikro ilişkilere etki eden, bireyin toplumsal alandaki konumunu yükselten veya düşüren bir otorite ölçeği/kaynağı olarak ifade edilebilir.

İtibar fenomeni kurumsal alandan toplumsal alana göre çekimlendiğinde karşımıza farklı bir içeriksel gerçeklikle çıkmaktadır. İtibar kavramının muhtevası/besleyici kaynakları, üretim safhaları, değer kaybı, toplumsal alanda çeşitli itibar tiplemeleri vb. ayrıntılar bu farklılığı somutlaştırır. Söz konusu farklııklara rağmen kurumsal itibar ile kişi itibarı arasında benzer yönlerin de varlığı yadsınamaz. Hem kurumsal hem de toplumsal alandaki itibar paydaşlarının sahip oldukları sembolik sermayeleri belirleyici bir güç olarak işlemektedir. Meşruiyet kaynağına bakılmaksızın etkileşim sahasında otorite elde etmiş itibarlı figürler, tabir-i caizse toplumsal her değişimin, sabitlemenin, normalin, normal olmayanın, iyinin, güzelin, doğru ile yanlışın, ekonomik, sosyal ve siyasal vb. mevzuların şekillendiği uğrak noktası yani düğüm noktası olarak imlenirler. Beşeri, kültürel, ekonomik sermayeye sahip hemen her eyleyen, toplumsal alanda otorite konumunda kabul görmeleri bunun en bariz özetidir. Belli kazanımlardan veya mirasla devralınmış güç, toplumsal işleyiş̧in dokusuna işlemektedir. Bu güç bireylerin beğeni algılarını, ilişki biçimlerini, hedef ve beklentilerini de yeniden üretmektedir. Toplumsal bir aktörün başka bir aktörle ilişkiye girmesi ya da girmemesi, itibarı var eden kaynaklardan birisine sahip olma(ma)sına yani muhatabın toplumsal alanda işgal ettiği konuma veya imaja bağlıdır. Dolayısıyla itibar kavramı sadece kurumsal yapıların marka değerini karşılayan bir kavram değildir. O, markanın imaj yükünü karşılamasına paralel olarak bireyin de sosyal alandaki saygınlığını veya konumunu ifade eder. Kurumsal yapıların itibar kaynakları toplumsal faydaya dönük bileşenlerdir. Kurumlar, atfedilen değerin kazanılması için uğraş içinde olur. Kurum itibarı kazanıımış bir güç iken birey itibarının hem atfedilen hem de kazanılan güç olduğu söylenebilir.

İtibar kavramının toplumsal alana özgü yönünü betimleyen bilimsel bir çalışmaya ulaşmak mümkün olmayabilir. Zira literatür içinde genel olarak kurumsal itibara ağırlık verilmiştir. Nicholas Emler 
(1990) A Social Psychology of Reputation (itibarın Sosyal Psikolojisi) adlı çalışması ile alana katkı yapmıştır. Türkiye'de ise kavrama yönelik bir çalışma yapılmamıştır. Bu çalışma alandaki eksikliği giderme anlamında ilk uğraş olarak değerlendirilebilir. Toplumsal işleyişi tanımlayan bir motif olarak itibarın bir araştırma konusu yapılmasının nedeni ya da amacı, şimdiye kadar böyle bir araştırmanın yapılmamış olması, toplum içinde bir birey olarak etkin bir faktör olarak itibarın önemine dair çıkarımdır. Bu bağlamda itibar kavramının hangi kaynaklarla tanımlandığı, belli değişkenlere göre anlamlı bir farklılığa sahip olupolmadığı ve benzer başka çalışmaların yapılmasının mümkün olma durumu üzerinde bir çalışma hazırlamaktır.

\section{BIR KARIZMA MITI OLARAK ITIBAAR VE KAYNAKLARI}

İtibarlı görünme uğraşı ya da muhatapların algısını bu yönde manipüle etme çabası, pek çok farklı argümanla sağlanan bir otorite çeşididir. Ekonomik göstergeler, tüketim pratikleri, beğeni yargıları, boş zaman etkinlikleri, eğitim seviyesi, ikamet edilen mekân iletişim ağları, aileden devredilmiş her türlü miras gibi sermaye motifleri toplum tarafından öykünen, uğruna mücadele verilen idealize bir yaşam biçimini süsleyen enstrümanlardır. Ancak sahip olduğumuz metalar ya da vitrini şekillendiren nesneler konumumuza, statümüze, saygınlığımıza olumlu yönde etki edemiyorsa itibarı devşirecek başka kaynakların arayışında oluruz. Zira, itibar ekonomik ve kültürel göstergelerle sağlandığı kadar beşeri karşıllı̆ı olan bir güçtür. Sanat, siyaset, ekonomi, spor, edebiyat, akademi gibi her türlü popüler alanı temsil eden figürlerle girdiğimiz etkileşim örüntüleriyle kendimize paye çıkarırız. Dolayısıyla bir otorite temsili olarak itibar, enstrüman portföyü oldukça geniş olmakla birlikte söz konusu enstrümanlar zamana ve mekana bağı kalmaksızın dönüşmekte ve çeşitlenmektedir. Bu değişime rağmen yadsınamaz bir gerçek vardır. $O$ da itibar popülaritesi, mutlak anlamda reel veya sembolik bir güce kapı aralar. Bireyin sahip olduğu kaynaklar ve bu kaynaklardan elde edilen gücün toplumsal alandaki temsiliyetinden, konumundan, prestijinden, imajından ya da ağırlığından mülhem karizmanın etkinlik alanı genişlemektedir. Toplumsal alanda itibar karizmasının geniş çapta var olan etkinliğinden esinlenerek kavramın taşıdığı değer yükü kurumsal yapılara da yakıştııımıştır (Gümüş \& Öksöz, 2010, s. 111-124). Kurumların da aynı eksende sahip oldukları ve olamadıkları, marka değerini artırmasını sağlayan ya da kurumsal güveni zedeleyen yönleriyle tüketici paydaşların nezdindeki pozisyonları tayin edilir. İtibar, bu söylemden yola çıkarak, en genel anlamda kazanılmış ya da bahşedilmiş bir saygınlık ve bu saygınlığın 
araçsallaştırılmasıyla elde edilen otorite gücü olarak özetlenebilir. Ancak otorite fenomeni kimileri için cazibeli bir imge iken bir başkası için korku duvarını çağrıştırabilir. Bu farklılık otoritenin sahip olduğu olanakların kurgulama biçimine yani gücün muhataplar üzerindeki dağılımına bağlı olarak şekillenmektedir (Sennet, 2011, s. 25-30). Ancak otoritenin gücün bir türevi olduğuna dair genel konsensüsten söz edilebilir. Gücün kullanımı konusu, sadece klasik anlamıyla muktedirin örtük ya da aleni dayatmalarından neşet ettiğini ve mutatlaştığını söylemek egemen olma gerçeğini güdük bırakır. Zira itaatkâr grup, belli çıkar arayışından ötürü otoriteye asgari düzeyde de olsa bir itibar atfeder ve dolayısıyla gücün meşru dolaşımına yol açar. Başka bir şekilde ifade etmek gerekirse, gücün reel olarak kullanımı, rıza üretme çabası otoritenin devamlılığını etkileyebileceği gibi bağımlı bireylerin itaatini zorunlu kılan altındaki gizil niyetler de yapının sürdürülmesine etki edebilir. Weber'in (2018, s. 331-341) geleneksel, karizmatik ve rasyonel otorite tiplerine yönelik tespitleri ve söz konusu otoritelerin zamanla dönüşümü toplumsal ilgi, saygı, beğeni, onaylama, rıza gösterme gibi oydaşımlar ekseninde değerlendirilebilir. Her bir otorite tipinde gücün dolaşımı kadar güce muhatap olan kesimlerin çıkarlarının da egemenliğin korunmasında dahli vardır. Söz gelimi, karizmatik aktörler "kurtarıcı" mitosla zayıf yapıya bir dinamizm kazandırabilir ve bu cazibe toplumsal alanda kahramanın otoritesini yani itibarını mümkün hale getirebilir. Ancak modern dönem rasyonel tiplere yönelik kabulün ya da onların meşruiyetinin daha ön planda olduğu/olacağı diğer tiplerin giderek silikleşeceği gerçeğine rağmen hâlâ geleneksel ve sıra dışı karizmatik figürlerin itibar görmesi ya da karizma tiplerinin itibarlarının rutinleşmemesi durumu, gerek itibar kaynaklarındaki çeşitliliği gerekse de bu tipoloji etrafında kümelenmenin nedenini ortaya koymaktadır. Öyle ki çeşitli dini, geleneksel karizmaların toplumsal rızayı elde etmeleri bir yana, başka bir çalışmanın konusu olabilecek, "mafya babaları" gibi otoritesi açık şiddete dayanan yapıların da itibara dayalı meşruiyet söylemlerine tabii olmaları önemli bir tartışma alanıdır.

İtibarın sözlükteki ve gündelik dildeki kullanımına bakarak kavramın içeriği netleştirilebilir. İtibar Türk Dil Kurumu sözlüğünde "saygın, saygı görmek, değerli, güvenilir olma ve prestijli" kavramlarına karşılık gelir (TDK, 2020). Cambridge Dictionary'de (2020) ise bir insana ya da nesneye yönelik genel düşünce olarak kavram tarif edilir. Reputation kelimesine karşılık gelen itibar ün, şan ve şöhret olarak da yorumlanmaktadır. Dikkat edileceği üzere ifade, yalın haliyle olumlu ve pozitif bir yüke sahiptir. Bir toplumsal eyleyene gündelik dil içinde "itibarlı" nitelemesi yapıldığında genel olarak onun güvenilir olduğuna ve bulunduğu sosyal çevrede genelleştirilmiş ötekilerden farklı bir kişilik yapısını temsil ettiğine 
vurgu yapılır. Bu haliyle kavramın genel olarak "özel insan" nitelemesi üzerinden anlam bulduğu görülmektedir. Bu pozitif ayrışma ya da farklılık, genelleştirilmiş ötekilerle girilen gündelik etkileşimlerle kazanılır. Ayrıca "özel insan" kimliğini besleyen önemli bir gerekçe de kaynakların niceliksel olarak kıt olmasına ve dolayısıyla niteliksel kıymetine vurgu yapar. Yani bir sosyal çevrede bulunan tüm bireyler borcuna sadık, sözüne güvenilir, insan haklarına saygılı, sorumluluklarının farkında gibi herkesçe kabul gören soyut sermaye niteliklerine sahip değildir. Eğitim gibi bireyin toplumsal statüsüne doğrudan etki eden kazanımlar, maddi olanaklar gibi toplumsal tabakaya etki eden göstergeler tüm toplumsal aktörler tarafından eşit oranda kazanılmadığından veya onlara dağıtılmadığından dolayı söz konusu verili sermaye türleri bireyi, hemcinslerine karşı ayrıcalıklı bir noktaya taşır ve bu ayrıcalık kendisini beslemede yeni hakların da tanınmasını sağlar. Bu normları kabul eden ve bu sermaye tiplerine sahip olan kitlenin niceliksel yoğunluğu az olduğundan ötürü onları çevreleyen halka tarafından imrenilir, taltif ve itimat edilir. Öteki bireyler, sosyal alan içinde ekonomik ve sosyal ihtiyaçlarını ve psişik hallerini genel olarak bu "özel insan" ile etkileşime girerek karşılarlar.

İtibarlı kişi olarak ifade edilen bireyler, sahip oldukları rezervler noktasında pozitif yönde farklılaşırlar. Bu rezervler parasal gibi kıymetli metalar bağlamında ekonomik sermaye ürünleri, aile, eğitim ve çeşitli sosyalleşme süreçlerinden sonra biriktirilen yaşam formuna dayalı kültürel sermaye, bağı bulunduğu yaşam alanında diğer sermaye türlerine sahip olanlara yakınlık üzerinden imlenen beşeri sermaye özelliklerine göre "özel insan" kategorileri belirlenir (Fowler, 2019, s. 59-61). Burada sahip olunan sermaye çeşitliliğine göre tipleştirme yapmamız mümkündür. Bu minvalde bireyin kültürlenme süreçlerinde kazandığı, davranışsal emekle üretilen, kişiliğin pozitif, ahlaki, teolojik, etik, hukuki normlara göre kabul gören ve dolayısıyla sosyal çevresi tarafından atfedilen pozisyonundan kaynaklı otorite tipi "saygın tip" içinde değerlendirilebilir. Ancak imaj ya da prestij sadece iyi davranışlardan yani kendinden soyutlanmış ve toplumsal yararı gözeten eylemlerden damıtılmış bir toplumsal kabul olduğu söylenemez. Toplumsal alanda ve algıda "değerli" olanı var eden bileşenler/kaynaklar/rezervler ve dolayısıyla bunlarla ilişki içinde olan bireyler de bu gruba dâhil edilebilir. En geniş sınıflandırmaya göre ekonomik sermaye, kültürel sermaye ve sosyal sermaye paydaşlarınca oluşan "seçkin tip" ikinci kategori olarak karşımıza çıkmaktadır. Ekonomik sermaye en basit ifadesiyle, para ve mülk gibi mali anlamda her nesneye sahip olma durumuna gönderme yapar. Kültürel sermaye de esasında eğitim gibi sosyalleşme yani kültürlenme alanlarıyla elde edilen birikmiş emektir yani habitusu şekillendiren desenlerdir. Sosyal 
sermaye alanı ise bireyin etkileşimde bulunduğu alandır (Akt: Aydemir, 2011, s. 45-53) Bu üç sermaye tipi birbirinin yerine kullanılabilir ve bu sermaye tiplerinden herhangi birisine sahip olan birey, bunları kişisel çıkarları için kullanabilir, pozisyonunu muhafaza edebilir ve beraberinde toplumdan itibarı devşirebilir. Bu gerçeklikten yola çıkarak sermaye olarak nitelendirilen bir nesne ya da simge, bağlı bulunduğu alan içinde işlenmesi ve alanın aktörlerine bir karizma kazandırma vasfıyla anlamlıdır.

Tipleştirme yapılırken iki temel varsayım merkeze alınmıştır. Birincisi, eyleyen eylemlerini toplumsal alanda sergilerken onu bir sermaye aracı olarak kurgulamaması varsayımıdır. Söz gelimi, şeref, onur, namus gibi soyut sembolik değerler ortaya konulurken "bu payeler için aleni kayıplar esasında örtük bir sermayeyi mümkün kılar. Bunu eyleyen farkında olsun ya da olmasın, istesin ya da istemesin toplum bizzat bu payeyi verir" (Joas \& Knöbl, 2019, s. 29-30). Farklı toplumsal alanlarda ilkece tutarlı bir kişilik kabulü söz konusudur. Öte yandan seçkin tip içinde bulunan aktörler, eldeki kaynaklarla ya prestijini koruma ya da onu yükseltme arayışında olduğu kabulüyle anlamlandırılmıştır. Bu anlamda sosyal sermaye teorisyenleri arasında toplumsal aktörlerin gündelik performanslarında ekonomik, sosyal ve siyasal çıkarlar/menfaatler için eylemlerini ürettiklerine dair genel bir konsensüs söz konusudur.

Niyetlenmiş eylem üzerinde çalışan sosyal bilimciler eylemi iki yönde ele alırlar: eylemin amacını ve amaca giden yolda yöntemin nasıl ve hangi enstrümanlarla kurgulandığını betimlemek. Eyleyen belli bir durum karşısında pozisyon aldığında duruşunu ya normun bağlayıcı esaslarına göre düzenler ya da eylemlerini/düşüncelerini/ilişkilerini her türlü getiriye tahvil ederek kurgular. Söz gelimi, yalan söylememek, borcuna sadık olmak, komşularını rahatsız etmemek, güvenilir olmak gibi değer yüklü edimlerle saygın bir kişilik inşası tahayyül edilebilir. Ilkece benimsenen bu değer dünyası bireyin diğer gündelik eylemlerine ya da diğer reaksiyonlarına akseder ve ondan tutarlı bir eylem kompozisyonu beklenir. Buna karşılık fail, her türlü müspet eylemi sergilerken bağı bulunduğu bağlam içinde bir konum/otorite elde etme mücadelesi verebilir. Dolayısıyla değer manzumesi muhatabı ayartmak adına kullanılan bir sermaye aracına dönüşür. Bourdieu'nun (2006, s. 149-152) faydacı ve yansıtmacı reaksiyonlardan arındırılmış bir eylemin ya da kişiliğin söz konusu olamayacağını ifade etmesi, esasında saygın eylemlerin çıkarı maskelediği, şeref, onur, izzet, namus gibi saygın etiketlerin altında bir çıkar olduğunu dillendirir (Joas \& Knöbl, 2019, s. 29-30). 
Faydacı, yansıtmacı ve statü kaygısı gibi gizil olarak niyetlenmiş düşünce kalıpları tipleştirmede turnusol görevini taşımaktadır. Turnusol kavramlar saygın tipi somutlaştırmak için kullanılmaktadır. Saygın, itibarlı, muteber ya da kıymetli olarak gündelik etkileşim ağı içinde yer edinmiş kişiler eylemlerinde mutlak anlamda basit ekonomik ya da başka kazanımlar ekseninde kişisel çıkarı önceleme durumlarını merkeze alır. Seçkin tip kategorisi esasında turnusolü çok daha somutlaştırmaktadır. Bu kategoriye dâhil olan kişiler, kurumsal yapıların kurumsallaşmış yönelimlerine paralel, eylemin ya da çeşitli sermaye ağının dolaşıma sokularak itibarın/prestijin/imajın sağlanması hedeflenmektedir. Bu noktada faydacı/çıkara dayalı eylem olarak işaret edilen eğilim rasyonel eylemin dayanak noktalarını şekillendirmektedir. Rasyonellik, bu eylem sarmalıyla gündelik hareketliliği tamamen yeniden üretmektedir (Ermakoff, 2015, s. 141-165). Elde edilen ekonomik, kültürel, beşeri sermaye türleri birbirlerini besleyebilir, aynı zamanda indas edilen konumu daha da muhkem hale getirebilir. Bu noktada saygın ve seçkin kişiler statü kaygısı, faydacı ve yansıtmacı reaksiyonlara karşı mesafeleri ile ele alınacaktır. Çünkü bu üç temel kavram, eylemin örtük niyetini betimleme özelliğine haizdir.

Çıkarcı ya da faydacı reaksiyonlar, her türlü kişisel niyetin ve varlıkların yeni bir kazanıma öncülük etmesi beklentisine göre stratejik olarak kurgulanmış durumu izah eder. Eylem örüntüleriyle muhatapların algıları veya rızaları "iyi ve ahlakı" davranışlarla manipüle etmeyi anımsatır (Swartz, 2013, s. 99-100). Aynı zamanda farklı varlıkları özellikle ekonomik mal biriktirmeye imkân tanır. Daha önce de ifade edildiği gibi sermaye yapılarının aynı amaca matuf kullanılabileceğine işaret edilmişti. Saygın kimselerin yaşam pratiklerini yine de Bourdieu'nun "çıkar" kavramına göre yorumlamak gerekirse; şüphesiz bu toplumsal tipler, eylemlerini "yatırım” amaçlı kurgularlar. Ancak kendisinden soyutlanmış ve toplumsal faydayı gözetleyen bir "çıkar" arayışına göre yatıım planları söz konusudur. Toplumsal fayda esasına göre ortaya konulan her eylem, düşünce ya da etkileşim örüntüsü, bulunduğu farklı mekân ve zamanda arasında bir çelişki içinde olmamasını gerekli kılar. Zira toplumda hemen her fert pratik bir sosyolog gibi eylemi var eden altındaki motivasyonun ne olduğunu gözlemleyebilir. Saygın bireylerin de çıkarı merkeze alarak performanslarını serdetmeleri pratik sosyologlar tarafından anlaşılabilir. Yani Goffman'ın (2020) ifadesiyle, saygın bir karakterin sahne önü ve arkasındaki performanslarının uyum içinde olması bu tipolojiyi "kendine odaklı" çıkarcı grupların dışında tutar. Çıkarı performans düzeyinde deneyimlemiş ve saygın tipoloji etrafında kümelenmiş bireyler, bu tipin kendi karakterini aşındıracak herhangi bir aksiyonunu anlamlandırabilir ve dolayısıyla tipin toplumsal konumu, statüsü de 
değersizleşebilir. O, çevresinde yalan söylemez, borcuna sadık, sözünde duran, başkasının canına ve malına kast etmez, diğerlerinin özgürlüğünü ihlal etmez gibi tercihler, ahlaki esaslara göre bezenmiş ilkeli bir tipi çağrıştırmaktadır. Saygın bir tipe dair en yakın bireylerle en mesafeli bireylerin olgusal düzeyde aynı söylemde bulunmaları bu iddiayı desteklemektedir. Bu doğrultuda aktörün toplumsal alanda ayrıcalıklı konuma mazhar oluşu onun eylemlerinden, düşüncelerinden, ilişki biçimlerinden hasılı tüm etkileşim örüntülerinden bağımsız ve toplum tarafından verilmiş bir paye olduğu düşünülemez. Bizzat bireyin olumlu eylemleri ve düşünceleri sonucunda birikmiş bir soyut sermaye alanı ya da davranışsal emeğin bir getirisi olarak kazanılmış bir statüdür. Dolayısıyla toplumsal alanda bu tipolojik özelliklere sahip bireyler muteber kişilikler olarak gösterilirler. İtibarlı aktörler kazandıkları bu ayrıcalıklı konumları vesilesiyle, toplumsal başka figürler üzerinde kural koyucu bir otorite olarak kabul görürler. Esasında sosyal dayanışma ağları içinde iyi-kötü, doğru-yanlış, güzel-ç̧irkin gibi kategorik referanslar bu otoritenin etki alanına göre de şekillenebilir.

Itibar tartışmalarında özellikle kurumsal yapıların itibar analizlerinde genel olarak toplumsal paydaşların kurum hakkındaki düşünceleri yani onlara atfettiği değerin boyutu olarak kurum itibarı belirlenir. Söz gelimi ulusal ya da uluslararası bir firma kendi marka değerini, kimliğini ve imajını dolayısıyla itibarını belirlemek istediğinde tüketicilerin markaya karşı memnuniyetine, güvenine, çıkarına, diğer rakip firmalarla kıyaslama ölçütlerine, ideolojik referanslarına, çevresel duyarlılıklarına, beğeni yargılarına vb. daha pek çok başlığa dikkat ederek ölçer ölçülmektedir (Ural, 2002, s. 83-93). Tüketicilerin kurumlardan beklentisi esasında diyalektik bir çıkar ilişkisinin belirtisi olarak yorumlanabilir. Tüketiciler bu talepleri aleni şekilde dayatırken kurumlar da bu taleplerin karşılandığına yönelik yansıtmacı bir sorumluluğu icra ederler. Bu misyonu yerine getirmek kurumun faydacı ilkelerine örtük bir şekilde hizmet eder (Esen, 2011, s. 292-293). Burada dikkat edilmesi gereken husus, kurumun yansıtmacı reaksiyonlar gösterirken esasında paydaşların algılarını onarma amacı içinde olduğudur. Bu gerçeklikten yola çıkarak itibarın, kişilerarası etkileşimlerde karşııklı ve bilinçli olarak nasıl yönetildiği ifade edilebilir. İtibar yukarıda kategorize edilen iki tipte farklı "faydacı" ve "yansıtmacı" gayelerin farklı şekilde işlediği ifade edilmelidir.

Saygın tip öncelediğinde onun faydacı ve yansıtmacı duruşu, çıkar beklentisinden arınık olduğu ve eylemlerin sorumluluk ve erdemlilik bilinciyle icra edildiği yukarıda belirtilmişti. Ancak seçkin tipe dâhil olan aktörlerin genel olarak hem faydacı hem de yansıtmacı planlı, kurgulanmış bir eylem kalıbıyla kurumsal yapılarla paralellik içinde olduğu ifade edilebilir. Söz konusu planlı ve kurgulanmış eğilim, belli 
bir kurallar silsilesine bağlı olarak yerine getirilir. Bu noktaya temas etmeden önce faydacı ve yansıtmacı yönün açıklığa kavuşturulması gerekmektedir. Faydacı tavır, sosyal teorilerde olgusal düzeyde bir kabul olarak ele alınmaktadır. Pek çok sosyal bilimci bu gerçekliğe göndermede bulunmuştur (Bourdieu, 1986, s. 241-258); (Coleman, 2010, s. 77-119); (Fukuyama, 2010, s. 140-170). Farklı parametreler bağlamında sermayenin hemen her görüntüsü esasında faydacı ve çıkar amacına göre düzenlenmekte; stratejiler, taktikler, kazanımlar-kayıplara göre sürekli geri bildirimler yaparak reaksiyonda bulunurlar. Bulundukları alanın kodlarına uygun olarak kazanımların nasıl elde edileceği ve hangi rasyonel eylemin dikişi sağlam tutacağı da yine habituslarına göre yani Bourdieu'nun (2006, s. 41-42) "oyunu okumak" dediği maharete bağıdır. Dolayısıyla seçkin olmak alanın, habitusun ve de habitusun bir bileşeni olan taktiklerin de seçkinci motiflerle bezenmiş olması beklenir. Söz gelimi, doktor, avukat, hâkim, asker gibi hiyerarşik bürokratik düzende üst katmanda olan bireyler bu kültürel kazanımlarını siyasette kamuoyu rızasını elde etmek gibi faydacı emelleri için kullanabilir.

Toplumsal alanda bu sermaye tiplerine sahip avantajlı gruplar sahip oldukları varlıklara göre ve yaşam pratiklerine bağlı olarak iktidarlarını sürdürürler. Yani yansıtmacı ve maniplatif gösterimlerle itibar devşirilmektedir. Yeme-içme pratikleri, giyim ve moda ilgileri, sosyal etkinlik tercihleri, sanat, edebiyat, siyaset, bilim gibi muktedir alanın bu edimleri kitlenin hazcı, tüketim, beğeni, gösteriş yönlerini manipüle etmek suretiyle yaygınlaşır. Esasında itibar, bir yönüyle de kitle tarafından ulaşılamayan ama her an bir izleyici pozisyonunda kalarak tecrübe ettiği konforlu yaşama değer atfetme olarak da okunabilir. Söz konusu hayat tarzı vasıtasıyla iktidar fenomeni gündelik yaşamın en mikro alanlarına kadar sirayet etmesi mümkün hale gelir. Dolayısıyla sahip olunan sermayenin değerine ve niteliğine göre tabakalaşmış toplumsal yapılar, dezavantajlı gruplardan herhangi bir direniş görmeden kendi iktidar alanlarını sürdürmekteler (Swartz, 2013, s. 18-19). Foucault, iktidarın tekelleşmesine ve onun "baskıcı hipotez" oluşuna karşı çıkarak yeniden yorumlaması da bu gerçekliğe gönderme yapar (Akt: Mills, 2003, s. 113130). Yani iktidarın baştan çıkarma gücü yumuşak bir söylem, yaşam pratiği ve örtük bir dayatma yoluyla sürekli üretilmektedir. Beğeni, gösteriş, çıkar gibi motivasyonlar, Bourdieu'nun anlamaya çalıştığı şeyin yani iktidarın/itibarının direnç görmeden yayııımına imkân tanımaktadır. Sosyal yaşamımızda sermaye odaklarına ait iktidar örüntülerini sıklıkla deneyimlemekteyiz. Söz gelimi, itibar fenomeniyle de paralel olarak, zengin bir iş adamı ya da sanatçının magazin programlarıyla tüketim alışkanlıklarını özümsemekteyiz. Mafyatik tiplerin özendirici halleri, bürokrasinin üst kademelerinde bulunan bireylerin 
yaşam şartları, ulusal ve uluslararası alanda tanınmış simaların hemen her davranışı kitle üzerinde ayartıcı bir etkiye sahiptir. Bu tür örnekler daha da çoğaltılabilir. Ancak konunun mihenk noktası da esasında bu iktidar biçimlerinin yumuşak şekilde kurgulanmasından ziyade, toplumun bu dolaşımın bilincinde olmasına rağmen neden tepkisiz kaldığını ve teolojik, ahlaki, hukuki olarak meşruiyeti tartışılan güç fragmanlarının da bu dolaşımda olmasıdır. Üstelik bu fragmanlara onur, itibar, saygınlık, değer atfedilmesidir.

Saygın ve seçkin itibarlı tiplere yönelik değer atfedilmesi konusuna da temas edilmelidir. Her ne kadar itibar yansıtmacı ve faydacı içeriklerle üretilmiş olsa da bu otorite tipleri etrafında kümelenme de itibar üretmenin başka bir yönünü de açığa çıkarmaktadır. Zira Bourdieu'nun "çıkar"a dayalı hipotezi, kitlenin rasyonel tercihini de şekillendirmektedir. Kitle de itibarlı figürlerle ilişki içine girerek ekonomik, sosyal, kültürel ve siyasal alanlarda itibarını üretme gayretinde bulunurlar. Seçkin bireylerin yaşam formu idealize edilerek özümsenir. Kendisini avangart, ideal, ince zevkli, seçkinci kültürün terbiyesinden nasiplendiğini, dolayısıyla üst kültürel manzume üzerinden seçkin tipe kendilerini entegre ederler. Dolayısıyla itibar kurucu vasfa sahip olduğu kadar rizomatik bir seyir izleyerek başka ama daha az itibarlı bireylerin de toplumsal alanda güç ilişkilerine girmesine imkân tanımaktadır. Bireyler sosyal çevresindeki sermayesiyle muhatabını ayartmaya çalışır. Söz gelimi, siyasette üst makamlarda görev almak, mafya babalarından birini tanımak, bilim insanlarından biri ile irtibatlı olmak gibi örnekler soyut getirilere kapı aralayabilir. Bu noktadan sonra çalışma itibarın üretim kaynakları bağlamında resmedilecektir. Üretim kaynakları da sosyal, kültürel ve ekonomik göstergeler olarak ifade edilebilir.

\section{AMAÇ VE YÖNTEM}

İtibar kavramı kurumsal yapıların toplumsal algıdaki yerini belirleyen başat bir kavram olarak kullanılmaktadır. Ancak kavram, sadece kurumsal yapıların sembolik yükünü belirlemede referans değildir. Bu kavram, aynı zamanda gündelik yaşamımızdaki etkileşim pratiklerimizi belirleyen etmenleri de tanımlamak için kullanıı. Saygınlık, sınıf, statü gibi çeşitli sermaye kaynakları ilişkilerimizi belirlemekte ve bu kaynaklar, bağlı bulunduğu alana özgü itibarlı figürleri inşa etmede rol oynarlar. İtibara dair literatür incelemesinde çalışmamız için genel olarak aşağıdaki araştırma soruları belirginlik kazanmıştır. 
1. İtibar kaynakları nelerdir?

2. Cinsiyet, ahlak ve inanç olguları itibarı ne şekilde etkiler?

3. Kültürel, sembolik, ekonomik, sosyal sermayenin temel kaynakları dışında başka mikro itibar kaynakları var mıdır?

Bu vesileyle itibar fenomenine toplumsal alanda, kurumsal yapılardan bağımsız olarak, kullanılmasına etki eden faktörlerin neler olduğunu belirlemek amacıyla başvurulmuştur. İtibar çalışması kurumsal yapılardan gündelik etkileşim örüntülerine kaydırıldığında çeşitli metodolojik zorlukları da beraberinde getirmektedir. Bu zorluklar örneklemin belirlenmesi, toplumsal algıda itibara dair ifadelerin damıtılması, yöntemin şekillenmesi vb. konuya özgü nedenler gösterilebilir.

\section{Örneklem}

Örneklem konusu nitel ve nicel araştırmalarda önemli bir konu olarak karşımıza çıkmaktadır. Örneklemin ne olduğu, nasıl seçilmesi gerektiği ve evreni temsilen örneklemin ne kadar seçileceği ile ilgili bir zorluk söz konusudur. Büyük bir grubu temsil eden tüm paydaşlara ulaşmanın mümkün olmamasından dolayı evreni temsil eden belli özellikte kişileri seçerek örneklem belirlenir (Neuman, 2017, s. 319-320). Bu çalışmada, itibar çalışmasında çeşitli değişkenleri merkeze alarak ölçüm amaçlanmıştır. Yaş, cinsiyet, eğitim durumu, maddi güç gibi değişkenlerle örneklem somutlaşmıştır. Araştırma verileri yüz yüze görüşme tekniğiyle 2019 yılının Eylül-Ekim aylarında, Konya il sınırlarında toplanmıştır. Konya'da yaşayan 14 yaş ve üzeri bireylere ulaşılmıştır. Çalışma için seçilen yaş aralığıı çalışma öncesi farklı yaş kategorileri ile yapılan görüşmeler, ön test ve uzmanların görüşleri dikkate alınarak belirlenmiştir. Kuşaklar arasında bir kıyas yapılmamış olup ifadelerin katılımcılar tarafından anlaşıımasına özen gösterilmiştir. Katıımcılardan araştırmaya katılmaları için rızaları alınmış ve gönüllülük esasına göre görüşmeler gerçekleştirilmiştir. Kotalı örneklemle seçilen toplam 850 kişi ile görüşme yapılmış, bunlardan 19 tanesi önemli sorulardaki eksik verilerden dolayı çıkarılmış ve analizler, 831 kişiden elde edilen verilerle gerçekleştirilmiştir. Kotalı örneklem ise belli değişkenlere bağlı kalarak katılımcıların seçilmesini ifade eder (Neuman, 2017, s. 322). Konya ili ile sınırlı olacak şekilde cinsiyet, yaş ve kuşak değişkenleri örneklem içinde kotalı olarak belirlenmiştir. Ancak ifadelerin cinsiyet değişkenine göre farklılık arz etme ihtimaline binaen cinsiyet değişkeninin kotalı olmasına daha çok hassasiyet gösterilmiştir. Veri toplama safhası öncesi, hazırlanan soru formu 50 kişiyle ön test yapılmıştır. Akabinde 
uzmanlarla veri toplama teknikleri ve içeriklerine dair de görüşmeler gerçekleştirilmiş ve sonrasında veri toplama kaynağına son şekli verilmiştir.

\section{Ölçme ve iş̧lem}

Araştırmada kullanılan soru formu iki kısımdan oluşmaktadır. Birinci kısımda katılımcıların demografik özelliklerine odaklanılmıştır. İkinci kısımda ise ön test ve uzman görüşleri neticesinde şekillenen ifadelerin beşli likert ölçeğiyle itibarın toplumsal kaynakları elde edilmeye çalışılmıştır. Çalışmada herhangi bir hazır ölçek kullanılmamıştır. 40 ifadeden oluşan itibarın toplumsal kaynakları ölçeği, 50 kişi üzerinden yapılan ön test ve uzman görüşü ile 30 ifadeye düşürülmüştür. İşlemeyen ifadeler çıkartılmıştır. Çalışma keşfedici ve betimleyici araştırma türü bağlamında yapılmıştır. Keşfedici araştırma bir konunun bir veya birden fazla boyutunu ortaya çıkarmak, onun ne olduğu, nasıl olduğu vb. soru grupları ile anlama ve anlamlandırma sürecini kapsar. Betimleyici araştırma ise bir konu, durum ya da problemi sistematik şekilde ifade etmeyi sağlar (Kumar, 2011, s. 10-12) Bu araştırma türleri iki temel nedenden dolayı tercih edilmişstir. Birincisi, itibarın sosyal hayat içindeki etkinliğinin ne düzeyde olduğu, hangi kaynaklar bağlamında anlam kazandığı, itibarın çeşitli değiş̧kenlere göre nasıl anlamlandııılığını anlamaktır. İkincisi ise, birinci nedene bağlı olarak, itibara dair daha kapsamlı bir çalışmanın yapılma olanağının test edilmesidir. Görüşmede itibar kaynakları ile ilgili onlarca ifade sorulmuş ve anlamlı bulunan maddeler bağlamında bu başlık somutlaşmıştır. Bireylerin itibar algılarıyla örtüşen ifadeler, "1 Hiç katılmıyorum" dan "5 tamamen katıııorum" a doğru değişen 5'li likert tipi bir ölçekle ölçülmüştür. Sırasıyla temalara göre ayrılmış itibar fenomeni varimax rotasyonlu faktör analizi uygulanarak gruplandırma yapılmıştır. Buna bağlı olarak hem ölçeğin tümünün hem de elde edilen faktör gruplarının güvenirlik değeri (Cronbach's Alpha) de ölçülmüştür. Faktör yapılarıyla sosyo-demografik değişkenler arasındaki ilişkilerin gösterilmesi için t-test ve ANOVA analizleri gerçekleştirilmiştir.

\section{BULGULAR}

Bulgular kısmında itibarın toplumsal kaynağı ile ilgili ifadelerin kendi aralarında temalaşmasına yönelik çıktıların verilerine yer verilecektir. Temalar sosyal, kültürel, ekonomik ve sembolik sermaye kaynaklarına sahip olma ve bu sahiplik üzerinde toplumsal algıda "normal/ideal" görülen tipolojik görüntüleri ifade etmek üzere kurgulanmıştır. Söz gelimi, ilk tema olan "güven" konusu, kültürel normlarla ya da sermayelerle üretilmekte ve akabinde sosyal sermayenin de anlam bulmasına aracılık 
eden sembolik ve soyut bir kaynak olarak işlev görmektedir. Güvenin hem kültürel dokuya hem de sosyal ilişkilere yansıyan etkisiyle normal, değerli, kıymetli vb. olan/olmayan eylemlerin/niyetlerin somutlaşmasına etki etmektedir. Dolayısıyla güvene benzer olarak, diğer temalar da gündelik işleyiş içinde eylemlerin yönünü tayin etmesiyle ele alınmaktadır. Buna bağlı olarak toplumsallaşmaya dair bitimsiz üretimi yeniden üretmektedir.

İtibar fenomenini besleyen kaynaklar belli değişkenlere göre farklılık arz etmesi beklenir. Cinsiyet, eğitim durumu, kuşak, statü, sınıf vb. değişkenler itibara, birbirinden farklı gerekçelerle etki edebilir. Kadınlar, söz gelimi, genel olarak itibarı güvene dayalı algılarken erkekler daha farklı olarak statü veya asabiyet fragmanları üzerinden itibar kaynaklarını sahiplenebilir. Bu ve benzeri varsayımlar ekseninde çalışma şekillenmiştir. Çalışmada analize dâhil edilen toplam katılımcı sayısı 831 kişidir. Söz konusu 831 katııımcının eğitim durumu, yaş ortalamaları, kuşak dağııımları ve cinsiyet oranları ekte yer alan Tablo-1'de gösterilmiştir.

Tablo 1 Araştırmaya Katılanların Demografik Özellikleri

\begin{tabular}{lcc}
\hline & FREKANS & YÜZDE \\
\hline Cinsiyet & & \\
\hline Kadın & 422 & 50,8 \\
Erkek & 409 & 49,2 \\
\hline Eğitim Düzeyi & & \\
\hline Illkokul & 77 & 9,3 \\
Ortaokul & 61 & 7,3 \\
Lise & 160 & 19,3 \\
Üniversite & 465 & 56,0 \\
Lisansüstü & 68 & 8,2 \\
\hline Kuşak Dağııııı & & \\
\hline Z kuşağı & 181 & 21,8 \\
Millenium kuşağı & 313 & 37,7 \\
X kuşağı & 295 & 35,5 \\
Boomers & 42 & 5,1 \\
Toplam & $\mathbf{8 3 1}$ & $\mathbf{1 0 0 , 0}$ \\
\hline Yaş Dağılımı & & \\
\hline Yaş Minimum & Yaş Maksimum & Yaş Ortalama \\
\hline 14 & 80 & 31,6 \\
\hline
\end{tabular}

İtibarın toplumsal kaynağına yönelik ifadelere keşfedici faktör analizi (exploratory factor analysis) uygulandığında 8 faktör çözümü (boyutu) elde edilmiştir. Öncelikle veri setinin faktör analizine uygunluğunu görmek için yapılan istatistiklerde KMO değeri ,840 çıkmıştır. Bu değerin 0,50'nin üzerinde 
çıkması, örneklem büyüklüğünün ve veri setinin faktör analizi yapabilmek için yeterli olduğu anlamına gelmektedir. Barlett testi sonuçları da ki-karenin 0,01 düzeyinde anlamlı olduğunu dolayısıyla, verilerin çok değişkenli normal dağılımdan geldiği ve faktör analizinin diğer sayıltısının karşılandığını göstermektedir (Hinton, McMurray, \& Brownlow, 2014); (Çokluk, Şekercioğlu, \& Büyüköztürk, 2012). Faktör analizlerinde ölçek içinde geçerli sayılan faktörlerin (boyutların) varyansa yaptığı katkının oranı önem arz eder. Bu çalışma özelinde, özdeğeri (eigenvalue) 1'in üstünde olan sekiz faktör, varyansın, \%77,5'ini açıklamaktadır. Bu konuda yapılmış karşılaştırma yapabileceğimiz bir çalışma olmamasına rağmen göreceli olarak bu açıklama oranının yüksek olduğu söylenebilir. İlk faktör varyansın \%13.1 oranını açıklarken devam eden faktörler düşük oranda küçülmekte ve son faktör \%6.4 oranına tekabül etmektedir. Faktör analiziyle birlikte test edilen ifadelerin genel güvenilirlik analizi oldukça yüksek bir oranda çıkmıştır (Cronbach's Alpha= ,869). Bu çalışma ekseninde şekillenen temaların cinsiyet, eğitim ve kuşak değişkenlerine bağlı olarak herhangi bir anlamlı farklıık arz etme durumunu da irdelemiştir. Faktör çözümlerinde eğitim ve kuşak değişkenleri bağlamında anlamlı bir farklılık gözlenmemiştir. Öte yandan dördüncü ve beşinci faktörlerde cinsiyet bağlamında anlamlı bir ilişki söz konusudur. Aşağıda itibarın toplumsal dayanaklarına yönelik ifadelere uygulanan keşfedici faktör analizi sonucu elde edilen 8 faktör yapısı ayrı ayrı belirtilip tartışılmaktadır. Varimax rotasyonlu faktör analizi sonucunda faktör çözümleri altında bir araya gelen ifadeler, bu ifadelerin ortalama değerleri ve faktör yüklemeleri Tablo-2'de gösterilmektedir.

Tablo 2 İtibarın Toplumsal Kaynakları ile Illgili ifadelerin Varimax Rotasyonlu Faktör Analizinin Sonuçları

\begin{tabular}{|c|c|c|c|c|c|c|c|c|c|}
\hline & & F1 & $\mathbf{F 2}$ & F3 & $\mathbf{F 4}$ & F5 & F6 & F7 & F8 \\
\hline Faktör 1: İtibarın güven bağlamında üretimi & Ort. & \multicolumn{8}{|c|}{ Faktör Yüklemeleri } \\
\hline İtibarlı insan aleyhine de olsa sözünü tutar & 4,287 & 911 & & & & & & & \\
\hline İtibarlı insan borcuna sadık olmalıdır & 4,418 & ,863 & & & & & & & \\
\hline İtibarlı insan sorumluluktan kaçmamalıdır & 4,354 & 829 & & & & & & & \\
\hline $\begin{array}{l}\text { İtibarlı insanın en önemli özelliklerinden biri } \\
\text { güvenilir olmasıdır }\end{array}$ & 4,482 &, 758 & & & & & & & \\
\hline \multicolumn{10}{|l|}{$\begin{array}{l}\text { Faktör 2. Saygın-Seçkin Tip Arasında } \\
\text { Medcezir: İtibarın Farklı Üretmesi }\end{array}$} \\
\hline $\begin{array}{l}\text { Namaz kılmasına rağmen faizle ticaret yapan } \\
\text { kişi itibarını zedeler }\end{array}$ & 3,584 & & 902 & & & & & & \\
\hline $\begin{array}{l}\text { Dindar olarak tanınan birinin piyango ya da iddia } \\
\text { oynaması saygınlığına zarar verir }\end{array}$ & 3,701 & & 900 & & & & & & \\
\hline
\end{tabular}


Dindar olarak tanıdığım biri gece âlemlerine

3,848

, 894

katılırsa saygımı kaybeder

Faktör 3. İtibarın Sorumluluk Bağlamında

Üretimi

3,552

İtibarlı kişi arkadaș arasında arabulucu olmalıdır

3,656

, 921

İtibarlı insan yumuşak huylu olmalıdır

3,582

, 745

\begin{tabular}{|c|c|c|}
\hline $\begin{array}{l}\text { Faktör 4. İtibarın Erkek Cinsiyeti Ekseninde } \\
\text { ifade edilmesi }\end{array}$ & & \\
\hline Zorla birine bir şey yaptırmak itibar kazandırır & 1,405 & 903 \\
\hline $\begin{array}{l}\text { Toplumda ismi duyulmuş mafya babalarını } \\
\text { tanımak itibar kazandırır }\end{array}$ & 1,507 & 889 \\
\hline Çok eşlilik itibar kazandırır & 1,361 & ,834 \\
\hline
\end{tabular}

\section{Faktör 5. İtibarın Kadın Cinsiyeti Bağlamında}

Üretimi

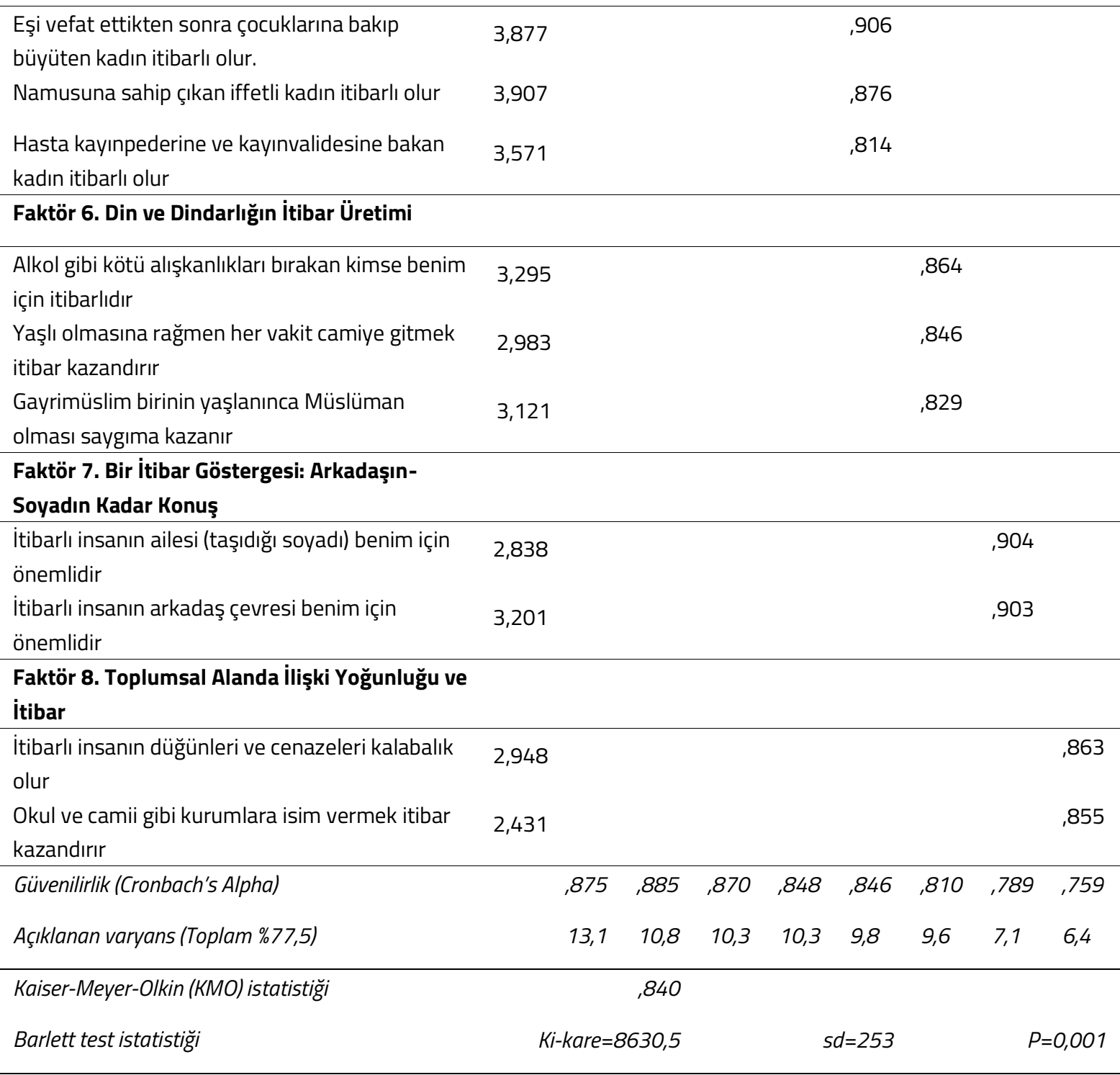




\section{Vazgeçilmez İtibar Miti: Güven}

İtibar toplumsal alanda üretilen bir fenomendir ve bu fenomen neticesinde aktörler bağlı bulundukları etkileşim alanında eylemlerini anlamlandıırlar. Söz gelimi, evlenirken karşı cinste aranan özellikler birer itibar kaynağı olabilir. Sosyal çevrede onlarca insan varken biri ya da birkaçı üzerinde ilişki kurmak da güven ya da saygınlık mefhumunu öne çıkarmaktadır. Buna bağlı olarak etkileşim alanından bir ya da birkaç insanı dışlamak da muhatabımızda belli olumsuz edim veya çeşitli göstergelerden mahrum olma durumundan mülhem itibar gösterilmemektedir. Bu bağlamda toplumsal alanda itibarın dolaşımı, genel olarak ahlakı var eden eylemlerin serdedilmesi neticesinde var olur (Inam, 2003, s. 1326). Güven, itibar üretici bir kaynak olarak işlev görmesi neticesinde bu çalışmada yer almıştır. Güven toplumsal bütünlüğün vazgeçilmez bir harcı olarak kadimden bugüne varlığını sürdürmüştür. Güven, muhataplar arasında belli bir etkileşimden sonra beliren bir değere bağlı bir sermaye kaynağıdır. Birine güvenmek beraberinde bir başkasına güvenmemeyi çağrıştırmaktadır. Birine güvenmek ve diğerine güvenmemek meselesi aktörlerin ilişkileri neticesinde elde edilen bir veri seti olarak yorumlanabilir. Borcuna sadık olma, sözünde durma, aleyhinde dahi olsa geri adım atmama, yalan söylememe, başkasında olan bir değere tecavüz etmeme gibi tutum ve davranış güveni beslemektedir. Bu pratikler sonucunda kişi bağlı bulunduğu sosyal çevresi içinde "saygın" bir otoriteye sahip olmakta ve etkileşim örüntülerini yoğunlaştırabilmektedir. Bu bağlamda yapılan çalışmada belli ifadeler test edilmiştir. Test edilen ifadelerde esasında aranan tema, itibarın toplumsal alanda hangi kaynaklar dolayımında anlam bulduğuydu. İtibar, teorik çerçevede, saygın ve seçkin tipler bağlamında resmedilmiş ve saygın tipin, eyleyenlerin tutum ve davranışlarında herhangi somut bir beklenti içinde olmadan sergiledikleri ve somutlaştırdıkları bir olgu olarak ifade edilmişti. Keşfedici faktör analizi sonucunda elde edilen ilk faktördeki önermelerde de "güven" nosyonu ön plana çıkmaktadır. Güven fenomenini çağrıştırdığı anlama göre saygın tip içinde konumlandırmak mümkündür. İtibarın toplumsal alanda değer yüklü bir etiket olması için öncelikle belli sorumlulukları taşıması beklenmektedir. Söz gelimi, toplumun, birine itibarlı yakıştırması yapması için ya da itibar mefhumu içinde, itibarı besleyen ilk kaynaklar arasında güven ve güveni anlamlandıran yan faktörlerin ilk elden olması kabulü yatmaktadır. Faktörde yer alan "İtibarlı insanın en önemli özelliklerinden biri güvenilir olmasıdır" ifadesinde güven kavramına vurgu yapılmıştır. Bu ifadenin 4,482 gibi tüm ifadeler içerisinde en yüksek ortalama değere sahip olması, paydaşların güveni itibarlı tipi seçerken öncelikleri arasına aldıklarının bir göstergesidir. Akabinde yan 
kaynaklar da benzer oranlarda seçilmiş ve dolayısıyla saygın tip içinde güven önemli bir soyut sermaye kaynağı olarak somutlaşmıştır. Çalışmayı oluşturan diğer temalara nazaran daha fazla kabul gören güven teması, itibarı oluşturan en önemli sermaye kaynağı olarak ifade edilebilir. Güven faktörünün toplam varyansa yaptığı katkı \%13,1 oranı ile diğer faktörler içinde en yüksek değere sahip olmuştur.

\section{Bir Adam İki Hayat: İtibarı Zedeleyen Ameller}

Din, sahip olduğu sembolik değeri ile güvenin en önemli besleyici kaynaklarından biri olmuştur. Din kurumunun sahip olduğu bu güven helezonu, esasında, kaynağını tanrıya karşı kulluk, boyun eğme, teslim olma, onun rızasını arama, sorumluluk hassasiyeti gibi gözetlenmekte olan bilincin çeşitli korkuümit sarkacı etrafında şekillenen kişiliğin muhataba verdiği sembolik kabuller çerçevesinde anlam bulmaktadır. Bir dinin ürettiği kimlik, değer ve motifleri taşımak yani dini temsilleri yaşam pratikleri içinde bilinçli ve isteyerek göstermek veya kamusal etkileşim alanında görünür şekilde dini çağrışımlara yer vermek beraberinde çeşitli kabulleri, yükümlülükleri, beklentileri de getirir. Söz gelimi, semavi dinlerde insan öldürmek büyük günahlardan biri sayılmaktadır. Dinin inşa ettiği kimlik kabulünde, herhangi bir semavi din paydaşından bu yönde bir aksiyon beklenmez (Yavuz, 2003, s. 27-52). Dolayısıyla din mefhumu bağlamında inşa edilen kimlik ve bu kimliğin gündelik etkileşim içindeki varlığı muhatabı olumlu anlamda uyarmakta, en azından bu korkularla oluşabilecek mesafeyi/engelleri kaldırmaktadır. Ancak dini değerleri özümseyen bireylere karşı güven beslenirken aynı zamanda dindarın dinin emrettiği kuralları kabul etmesi ve onu yaşamına yansıtması beklenir. Söz gelimi, Müslüman bireyin faizle ticaret yapması, içki içmesi, hırsızlık yapması, iftira atması vb. yasaklara tevessül etmemesi beklenir. Bu tür yasaklı alana dâhil olmak ve İslam kimliğinden farklı rollerde bulunmak beraberinde dine ve dindara karşı pek çok olumsuz toplumsal kabulü üretebilir. Bu çalışmada da dindarın haram veya yasaklı olarak ifade edilen alanlarda varlık göstermesi, onun dini kimlikten kazandığı saygınlı̆ın yani sembolik itibarın nasıl anlamlandığına odaklanmıştır. Piyangodan para kazanmak, faizle ticari etkinliğin genişletmek veya gece alemlerine katılmak seçkinci olma arayışının tezahürleri olabilir. Saygın kodları terk etmeden seçkinci enstrümanlara sahip olmak yani hem saygın hem de seçkin olma mücadelesi beraberinde mevcut itibarı zedeleyebilir. Esasında bu tutumlar turnosol veriler olarak değerlendirilebilir.

Din kurumunun inşa ettiği güven sermayesi beraberinde itibarı/otoriteyi/saygınlığı da var edebilir. Aktör gündelik yaşamında dinin emir ve yasaklarını hayatına yansıtması ekseninde saygınlık 
kazanır. Haramlardan sakınmak, kul hakkına girmemek, yalan söylememek, iftira atmamak gibi pozitif yüke sahip eylemleri sergilemek gerekir. Ancak dinin emrettiği kimliğin doğasına uygun ibadetler ile yasaklı, haram eylemlerin bir arada olması da beklenmez. Ortaya konulan kimliğin benzer eylem kümesi üzerinden anlam bulması tabi olandır. İkinci faktör dindar olarak tarif edilebilecek bir tip dolayımında aykırı eylemlerin itibarı yani saygınlığı nasıl etkilediğini göstermektedir. Faktörü oluşturan ifadeler 3.5 üstü ortalama değerde çıkmıştır. Dolayısıyla her bir katıımcı için yüksek oranda dindar tipin belli aykırı eylemlerde bulunması, onun saygınlığına negatif yönde etki etmektedir. Buna bağlı olarak faktör güvenirlik testi de (Cronbach's Alpha) ,885 gibi yüksek oranda çıkmıştır. İkinci faktörün varyansa yaptığı katkı oranı ise \%10,8'dir. Bu faktör özelinde cinsiyet, eğitim ve kuşak değişkenlerine bağlı olarak herhangi bir anlamlı farklılık da ayrıca gözlenmemiştir.

\section{Saygınlığı Ayartmak: Sembolik Sermaye Kaynağı Olarak Arabuluculuk}

Toplumsal alanda bazı figürler sergiledikleri roller dolayısıyla diğer toplumsal üyelerden ayrılırlar. Ortaya konulan eylemin niteliğine göre ya pozitif ya da negatif değere mazhar olur. Atfedilen değerin niteliğiyle de kişi bağlı bulunduğu sosyal çevresinde kendisine uygun bir pozisyonu indas eder. Yaşlılara saygı göstermek, yardımsever olmak, arabulucu olmak, nasihat etmek vb. tamamen eyleyenin inisiyatifinde olan ve sorumluluk alanına giren eylemler eyleyiciye özel bir yer kazandırır. Arabulucu olmak da toplumda eşler, arkadaşlar/dostlar arasında gerginliği azaltmak, birbirilerini anlamak, maziye göndermede bulunmak ve muhatabın vazgeçilmezliğini hatırlatmak gibi misyonlarla adeta aile kurumu ve arkadaş ilişkileri için gayri-resmi, örtük bir danışma kurumu olarak işlev görür. Adeta toplumsal basıncı azaltmak adına tampon kurum vazifesine paralel bir kıymete haizdir. Bu gerekçeden dolayı arabulucu tipin toplumsal alanda nasıl bir otoriteye sahip olduğunu araştırmak maksadıyla bu çalışmada yer alan ifadeler üçüncü faktör olarak bir araya gelmiştir.

Sorumluluk alanına giren eylemlerin sosyal çevrede serdedilmesi kişilere önemli bir saygınlık kazandırdığı ifade edilmişti. Faktör bileşenlerinin ortalama değerlerine bakıldığı zaman her ifade için 3,5 üzerinde bir uzlaşı söz konusu. Bu uzlaşı, arabuluculuğun saygınlığı besleyen önemli bir etken olduğuna delalet eder. Güvenirlik testi (Cronbach's Alpha) de ,870 çıkmışıı. Saygınlık mefhumu yukarıda betimlenen iki temayla benzer sermaye biçimine sahiptir. Zira bu temalar daha fazla sembolik hafıza ile anlam bulur. Örtük işler, eylem stratejik manipülasyonlarla kurgulanmayabilir ve dolayısıyla tamamen 
çıkara göre yorumlanmayabilir. Bu özellikler söz konusu üç temanın da toplumsal oydaşımda yüksek çıkması şaşırtıı olmayabilir. Saygınlık faktörü varyansa \%10,3 değerinde etki etmiştir. Herhangi bir değişkene bağlı olmaksızın bütün toplumsal gruplar tarafından ifadeler kabul görmüştür.

\section{İtibarın Cinsiyeti: Erkek ve Kadın Rollerine Göre İtibar Kaynakları}

Çalışmada saygın tip, esasında aktörlerin, gündelik yaşamında her türlü maddi veya somut sermaye beklentisinden uzak, eylemlerini gerçekleştirmesi bağlamında ifade edilmişti. Ancak tüm eylem örüntülerinin aynı niyet etrafında şekillendiğini iddia etmek mümkün değildir. Çeşitli teorik söylemler ve özellikle itibarla ilgili beyanlar genel olarak kazanımları mümkün kılan stratejiler, planlar, niyetler etrafında şekillendiği ifade edilmiştir. Itibar, bu bağlamda sadece saygınlık teması ile şekillenmemektedir. Fiziksel ve maddi güç, otorite tipleri, cinsiyet, asabiyet, eğitim durumu gibi farklı parametreler itibarın var olmasını sağlayan başat nitelikler arasında sayılabilir.

Gündelik yaşamda itibarın, esasında rollere uygun eylemlerin icra edilmesine bağlı olarak üretildiği söylenebilir. Roller, belli değişken kodlarına bağımlı bir şekilde mutatlaşmış eylem örüntüleriyle toplumsal algıda "normal", absürt olmayan, beklenilen, yapıl(ma)ması halinde kınanan ve hatta tutarlı şekilde icra edilmesi halinde onur atfedilen kabullerdir. Cinsiyet, zaman ve mekâna bağı olmak kaydı ile belli eylemlerin aynı cinsiyete sahip bireylerin sürekli ortaya koyması sonucunda rol gerçeğini netleştirir. Kadın ve erkek temsilleri mutatlaşmış eylemler ve kabuller dolayısıyla beraberinde farklı rollerin icra edilmesini sağlamıştır. Erkeğin kadın, kadının erkek rollerine bürünmesi, toplumsal alanda sapma olarak nitelendirilebilir. Kurumsallaşmış rol beklentilerinin cinsiyet üzerinden tanımlanması, beraberinde cinsiyete göre itibar çağrışımlarına neden olmaktadır. Ancak bu kabuller zaman ve mekân bağlamında değişmesi de başka bir gerçek olarak karşımıza çıkabilir. Çalışmanın yapıldığı yer ve zamana bakıldığında bu iddianın desteklendiği görülmektedir. Tablo-2'de, zorla birine bir şey yaptırmak, mafya babalarını tanımak, çok eşlilik gibi erkek veya eril önermelerin bir araya gelerek 4. faktörü oluşturduğu ve ifadelerin ortalamalarının 1.3-1.5 arasında düşük düzeyde çıtığı görülmektedir.

Dördüncü faktörde yer alan bu ifadeler, sonuç odaklı bakıldığında, herkesin tevessül etmediği, sonucun da sadece bu yönde niyetlerini açık eden ve istediğini alan "kahramanlara" göndermede bulunduğunu göstermektedir. Faktörün güvenilirlik değeri ,848 gibi yine yüksek bir oranda çıkmış ve dolayısıyla ifadelerin doğruluğuna işaret etmektedir. Erkek kimliğinin güç, şan, şöhret gibi popüler 
karizma çağrışımlarına sahip olması ve bunun cinsiyet değişkeni bağlamında anlam bulması, beraberinde cinsiyete dayalı anlamlı bir farkın oluşmasını sağlamaktadır. Zira Faktör 4'te cinsiyet arasında anlamlı bir ilişki vardır ( $t=-5,458$; $s d=829 ; p=0,001)$. Erkekler bu faktöre kadınlara göre daha fazla önem vermişlerdir. Bununla birlikte erkek faktörün varyansa etkisi \%10,3 oranında olmuştur.

Erkek rollüne ait kabullenilmiş eylemler, dikkat edileceği üzere şan, şöhret, nam gibi soyut sermayeyi anlamlandıran ve bu göstergeler bağlamında devşirilen itibara göndermede bulunmaktadır. Öte yandan kadın kimliğine özgü rol ifadeleri, bir araya toplanarak beşinci faktörü oluşturmaktadır.

Kadın itibarına yönelik ifadelerde genel olarak 3,5 üstü bir ortalama çıkmaktadır. Buna bağlı olarak faktörün güvenilirliği de ,846 çıkmıştır. Kadın ve erkek rolleri arasındaki bu farklıık esasında eylemin saygın ve seçkin tipleştirme içinde konumlandırıldığı yer de önemlidir. Zira kadına yönelik önermeler genel olarak sorumluluk teması içinde yorumlanabileceği için daha çok çıkar amacı gütmeyen saygın tipe dâhil edilebilir. Erkeğe dair çıkarım ise kahramanlık söylemi öne çıkmasından dolayı seçkin kategori içinde konumlandırılabilir. Kadının sorumluluklarına dair faktör 5 'te tıpkı faktör 4 'te olduğu gibi cinsiyete dayalı anlamlı fark olduğu görülmektedir ( $t=-3,551 ; \mathrm{sd}=829 ; \mathrm{p}=0,001)$. Bu faktörün varyansa etkisi ise \%9,8'dir.

Faktör 5'te yer alan ifadelerden de görüleceği gibi kadın kimliğine özgü rol ifadeleri daha çok sorumlulukların ön planda olduğu, toplumsal yararı gözeten eylemlerin icra edilmesine bağlıdır. Erkeklerde çok eşlilik muteber görülürken kadınlarda ise aileyi korumaya veya sürdürmeye yönelik bir kabul söz konusudur. Cinsiyet değişkenine bağlı olarak farklılaşma neredeyse küre genelinde, içerik farklılaşsa da, gözlemlemek mümkündür. Coğrafya, din, kültür, zaman vb. etkiler iki cinsiyeti ayrıştırmıştır. Mitolojik söylemler, dinler, kültürler (habitüs) ve biyolojik etmenler erkek - kadın arasındaki benzersizliği belli gerekçelerle vurgulamıştır (Güvenç, 2011). Konya'da yapılan bu çalışmada kadın-erkek arasındaki bu farklılık da genel olarak dini, kültürel, mekânsal yansımalardan etkilenmiştir. Dindar, muhafazakâr, toplumcu bir kent görünümüne sahip Konya, aktörleri bu gerçekliğe göre şekillendirir. Kadına yönelik kabullerde dikkat edileceği gibi hem dini, hem toplumcu hem de kadın kimliğinin ev içi yönüne göre şekillenmiş̧tir. Erkek rolü de yine aynı gerekçelerle daha çok kaba kuvvet bağlamında anlamlandırılmaktadır. 


\section{Eylemi Dindarlaştırmak, İtibarı İslamileştirmek: Dinin İtibar Üretimi Üzerindeki}

\section{Etkisi}

İtibarın üretim kaynakları arasında din olgusuna ikinci faktörde değinilmişti. Ancak ikinci faktör saygın/itibarlı bireyin olumsuz/haram eylemler sergilediğinde itibarının yeniden nasıl üretildiğini ortaya koymuştur. Bu faktörde ise, ikinci faktörün farklı bir yansıması olarak, müslümanlaşmak/dindarlaşmak gibi dönüşümlerin itibarlı olmaya nasıl etki ettiğini resmetmiştir. Din, yukarıda da ifade edildiği gibi toplumsal barışı, huzuru, adaleti vb. pozitif misyonları içinde barındırmaktadır. 0 aynı zamanda helal haram ölçütleri ve başka kabullerle bir eylem alanını veya meşruluğu tayin eder. Eylem sahası içinde meşru, makul, normal, seçkin, itibarlı, kıymetli, değerli olan ve olmayan gibi ölçütler eylemin, algının, beğeninin, zevklerin doğasını belirler. Bu bağlamda dini tercihler ve tercihlerle görünür olan eylem ve ritüeller itibar ya da saygınlığa etki eder. Söz gelimi, faktördeki ifadelerden de görülebileceği gibi, alkol tüketmek, tecavüze yeltenmek, hırsızlık yapmak gibi pratikler İslam dininin helal alanına dâhil değildir. Dolayısıyla Müslümanlar nezdinde bu tür edimler ve edimleri gerçekleştiren eyleyenlerin bir saygınlığa sahip olması beklenmez. Helal olarak tavsiye edilen hususlarda eylemde bulunmak da bunun tam zıttı saygınlık kazanır.

Faktördeki ifadeler incelendiğinde haram olanı bırakıp helale yöneliş bir saygınlık vesilesi olarak görülmektedir. Özellikle dini tercihler ve dini emirler bağlamındaki yargılar çok daha öne çıkmaktadır. Din ve dindarlığın itibar üretimi faktöründeki ifadelerin ortalaması 3 civarında çıkmakta, güvenilirlik katsayısı ise ,810 olarak ölçülmüştür. Bu faktörde sosyo-demografik değişkenlere bağlı olarak anlamlı bir farklılığa rastlanamamıştır. Bununla birlikte bu tema varyansın \%9,6 oranında açıklamaya tekabül etmektedir.

\section{Bir İtibar Göstergesi: Arkadaşın-Soyadın Kadar Konuş}

Itibar olgusunu besleyen önemli bir başka kaynak ise aile ve sosyal çevredir. Bu kaynaklar sosyal sermayeyi anlamlandıran bileşenlerdir. Yani ailenin bulunduğu alandaki tanınmışlık durumu, ilişki kurulan arkadaşların veya ailelerinin sahip olduğu popülariteleri, taşımış oldukları soyadları dolayısıyla gösterilen saygının, aynı oranda kişiye de gösterilmesini ifade etmektedir. Yerel ölçekte örneğin Konya'da tanınmış eşraftan olmak veya soyadı çokça bilinen bir aileye mensup olmak verili bir sermayedir. Buna bağlı olarak "herhangi/sıradan" bir fail, kullanışlı bir sermaye aracına sahip olmadan sadece eşraftan biri ile ünsiyet kurma arayışında olma çabası da ikinci bir itibar kaynağı için elverişlidir. Bu ünsiyet ile bağlı bulunduğu 
sosyal çevresinde bunu dillendirerek yani bu ilişki üzerinden itibar damıtma stratejileri yaparak "herhangi/sıradan" olan konumunu yeniden revize edebilir. Yeni pozisyon alış, dolayısıyla daha farklı ve özenle seçilmiş bir kelime grubu ile nitelenmesine/tarif edilmesi imkân tanır. Ayrıca sosyal sermaye kaynă̆ı ile sıradanlıktan seçkinci olma hali, itibarın dolaşıma sokulmasına gizil olarak işlev görür. Söz gelimi, kişi sanatçı, sporcu, siyasetçi, entelektüel, doktor gibi farklı meslek dallarında ya da geleneksel bir toplumda kazanılmış sosyal, kültürel veya ekonomik sermayeleri ile ün kazanmış bir ailenin üyesi olabilir. Ya da bu aile ile arkadaş bağı üzerinden yakın temasa geçebilir. Bu temas da önemli bir itibar kaynağı olarak yorumlanan sosyal çevrenin niteliğine göre kazanılan bir sermaye türevidir. Aile seçimleri tercihlerimiz arasında değildir. Hangi aile üyesi isek onların sahip oldukları sermayeye razı olmak gerekir. Aile ekonomik, sosyal veya kültürel sermayeye sahip olabilir. OIması durumu, bireyler aynı habitusa sahip bir sosyal çevre edinir. Ancak arkadaş tercihleri aile gibi zorunlu bir kabul olmayabilir. Aktörler bilinçli yönelimleri ile yukarıda sayılan herhangi sermayedar tipleri ile ilişkiye kendisini zorlayabilir. Onun sahip oldukları üzerinden pastadan pay kapma amacı olabilir. Çalışmada aile ve arkadaş bağına yönelik 2 ifade bir araya gelerek yedinci faktörü oluşturmuştur.

Yedinci faktörde yer alan ilk ifade olan "Itibarlı insanın ailesi (taşıdığı soyadı) benim için önemlidir" ifadesi 2.83 ortalama değer almış ve faktöre oldukça yüksek düzeyde yükleme yapmaktadır. Soyadı, özellikle yerel/taşra mekânlarında bir güven ağı olarak işlev görür. Bir plan, iş, rica, emir vb. talepler soyadının verdiği sembolik yükle daha hızlı ve daha konforlu şekilde yerine getirilmesini temin eder. Soyadı en çok kız isteme, borç isteme, sözün senet kabul olduğu yerlerde geçerlidir. Diğer ifade olan "Iitibarlı insanın arkadaş çevresi benim için önemlidir" ise 3,20 ortalama değer ile yine yüksek oranda yükleme yapmaktadır. Yedinci faktör ,789 güvenilirlik katsayısı ile toplam varyansın \%7.1'ini açıklamaktadır.

\section{Namım yürüsün: İtibarın Sokaktaki Yansımaları}

Saygınlık, ün, popülarite, şan, şöhret gibi yakıştırmalar her ne kadar itibar ayartma nesneleri olsalar da yaşamda bütün kırılmaların, tercihlerin, seçimlerin aynı ayartmayı amaçladığı söylenemez. Bazı durumlarda bizi saran çevremiz bize bu yakıştırmayı yapar. Cenaze törenindeki katılımcı yoğunluğu, düğünlerde takılan takı miktarı ve ikramların çeşidi ve lüks göstergeleri pozitif yükü barındırmaktadır. Camii, okul, huzurevi, yurt ve başka hayratlara bağış̧ının isminin verilmesi veya bağış̧ının bu amaçla 
yardımda bulunması da olumlu bir getiriyi içinde barındırmaktadır. Özellikle Güneydoğu bölgesinde takı miktarı defalarca haber bültenlerine konu olmuştur. Bununla birlikte düğündeki kalabalık, cenaze toplantıları "mahşeri" vurgusu bunlardan birkaçıdır. Kurumlara isim vermek de kişinin zenginliğine, dindarlığına, iyi insan oluşuna yönelik toplumsal algıda yer edinir. Son faktör olarak toplumsal alanda ilişki yoğunluğuna yönelik iki ifade bir araya gelmiştir.

Faktörü oluşturan "itibarlı insanın düğünleri ve cenazeleri kalabalık olur" 2,9 ve "Okul ve camii gibi kurumlara isim vermek itibar kazandırır" ifadesi ise 2,4 ortalama değer alarak orta düzeyde bir katıımı gösterecek şekilde bulgulanmıştır. Faktörün güvenilirlik katsayısı kabul edilebilir sınırın üzerinde ,759 olarak çıkmış ve toplam varyansın \%6,4'ünü açıklamaktadır. Toplumsal alandaki ilişki biçimi ve yoğunluğun ve bu yoğunluğun belli törensel alanlarda kamusal bir değere tahvil edilmesi, bir değişkene bağlı olmaksızın tüm paydaşlar için geçerli olduğu söylenebilir.

\section{İtibarın Toplumsal Kaynaklarına Yönelik Faktörlerinin Doğrulanması}

Keşfedici faktör analizi (EFA) sonucunda ortaya çıkan ve yukarıda ayrıntılı bir şekilde tartışılan 8 faktör yapısının itibarın toplumsal kaynaklarının belirlenmesindeki etkilerini görebilmek için doğrulayıcı faktör analizi (CFA) gerçekleştirilmiştir. Doğrulayıcı Faktör Analizi sonucunda elde edilen Uyum iyiliği indeksleri aşă̆ıdaki tabloda gösterilmektedir.

Tablo 3 Uyum iyiliği İndeks Değerleri

\begin{tabular}{ccc}
\hline INDEKS & BULUNAN DEĞER & KABUL EDILEBiLiR SINIR \\
\hline CMIN/DF & 2,287 & $<3$ çok iyi \\
GFI &, 954 & $>, 95$ \\
AGFI &, 938 & $>, 80$ \\
CFI &, 973 & $>, 95$ çok iyi \\
RMSEA &, 039 & $<, 05$
\end{tabular}

Faktör yapısının Uyum İyiliği İndeks değerleri incelendiğinde öncelikle ki-kare/sd değeri 2,287 bulunmuştur. Bu değer, 3'ten küçüktür ve çok iyi uyumu göstermektedir (Hu \& Bentler, 1999). Öte yandan $\mathrm{GFI}=.954, \mathrm{AGFI}=.938$ ve $\mathrm{CFI}=.973$ değerleri elde edilmiştir. Her üç değer de çok iyi uyumu gösteren sınırlara karşıık gelmektedir. Son olarak RMSEA= .039 değeri modelin uyum değerlerinin yine çok iyi olduğunu göstermektedir. Bunun yanında ifadeler ile faktörler arasındaki standartlaştııılmış regresyon ağırlığı değerleri 0.50'nin üzerinde bulunmuştur. Bu sonuçlar itibarın toplumsal kaynaklarına yönelik ifadeler üzerinde gerçekleştirilen keşfedici faktör analizi ile elde edilen faktör yapılarının 
kullanılabilir olduğunu ve faktörlerin altında yer alan ifadelerle karşılıklı ilişki içinde olduğunu göstermektedir.

\section{SONUÇ VE TARTIŞMA}

İtibar kavramına genel olarak hemen her türlü kurumsal yapıların, toplum nezdindeki imajını test etmek maksadıyla başvurulmaktadır. Kurumlara güven, tüketim alışkanlıkları, hijyen, maliyet, liyakat vb. ölçütler imajı tanımlamaktadır. Ancak itibar, sadece kurumsal yapıların değerini belirtmede kullanılmaktadır. Gündelik yaşamda aktörler, muhatabın sahip oldukları ya da olamadıkları kaynaklar bağlamında ona bir değer, itibar, saygınlık, otorite, iktidar atfeder. Para, fiziksel karizma, meslek, asabiye, cinsiyet, güven, eğitim durumu, aile/sosyal ilişkileri, fiziksel güç vb. daha pek çok argüman itibarı mümkün kılar. Dolayısıyla bu çalışma, itibarın mikro ilişkilerdeki üretimine ve kaynaklarına odaklanmıştır. Çalışma Konya il sınırları içinde yapıımıştır. 14-80 yaş aralığında toplam 831 kişi ile anket veri toplama yöntemi kullanılarak verilere ulaşılmıştır.

İtibar çalışması, 23 ifade ve 8 faktör etrafında anlam bulmuştur. 8 faktörde genel olarak sosyal, kültürel, ekonomik ve sembolik sermaye türevlerinin toplumsal algıdaki yerini veya kıymetini merkeze almıştır. Bununla birlikte çalışmanın teorik kısmında ifade edilen "seçkin" ve "saygın" tipolojilerinin, eylemlerini inşa etme motivasyonları ve sahip oldukları rezervler bağlamında ürettikleri karizmanın yansımaları da ortaya çıkmıştır. Birinci ve üçüncü faktör genel olarak soyut sermaye bileşenlerine sahiptir. Sorumluluk, iyi niyet, güven, arabulucu olmak gibi nosyonlar bu faktöre anlam kazandırmaktadır. Dolayısıyla bu faktör tutarlı eylemlerle saygın kategorisine dâhil edilebilir.

İkinci faktör, esasında saygın ile seçkin tipolojiler arasındaki farkı şekillendirmesi yönü ile öne çıkmaktadır. Saygın olarak yorumlanabilecek tipolojiler, belli arayışlarla seçkinci olma durumu çakışmaktadır. Dindar olarak tanımlanan ve bu tanımlamanın toplumsal algıdaki "normallik" ile "anormal" durumların (gece alemleri, faizle ticaret, piyango) birlikteliğinde dindarlık itibarı sarsılır. Esasında anormal durumları betimleyen örnekler kendi başına itibarı sağlayabilir. Zengin olmak, gece alemlerine katılmak bağlı bulunduğu kuşak ve cinsiyet için bir karizma miti olarak işleyebilir. Bu çıkarım, diğer faktörlerde yer alan benzer ifadelere binaen yapılmıştır. Dolayısıyla saygın ile seçkin aktörlerin bağlı bulundukları alana özgü aksiyon göstermediklerinde sahip oldukları itibarı kaybedebilir. 
Dördüncü ve beşinci faktör esasında, bir önceki paragrafta ifade edilen iddiaları, somutlaştırmaktadır. Cinsiyet değişkeni ekseninde rollerin toplumsal algıdaki yerini örneklendirdiği görülmektedir. Kadın ve erkek temsiller sırasıyla, saygın ve seçkin tipolojiyi tanımlayan eylemlerde bulunurlar. Kadınlar, erkekleri seçkin yapan eylemleri sergilediklerinde sahip oldukları saygınlığı kaybedebilir. Erkeklerin sosyal sermaye bileşeni olan "mafya babaları ile ilişkide olmaları" onlara seçkinci tip içinde itibar kazandırabilir. Çok eşlilik de aynı bağlamda düşünülebilir.

Altıncı faktörde dinin itibarı nasıl etkilediği görülmektedir. Esasında dini itibar kaynağı olarak yorumlamak, çalışmanın yapıldığı Konya ili için geçerli bir çıkarımdır. Zira Konya muhafazakâr bir il olarak bilinmektedir. Bu kategoriyi var eden önermeler de saygın tip içinde ifade edilebilir.

Yedinci ve sekizinci faktörler sosyal sermaye bağlamında değerlendirilebilir. Bu faktörlerdeki çıkarım, bireylerin sosyal çevresinde etkileşim içinde oldukları diğer bireylerin sahip oldukları itibar üzerinden itibardan pay almalarını ifade etmektedir. Bir mekânda ismi tanınmış ailelere mensup olmak, bilindik bir soy ismi taşımak, cenaze ve düğünlerin kalabalık olması, bir kuruma isim vermek vb. sosyal sermayeyi beslemektedir. Bu iki faktörün niteliklerine haiz aktörler, seçkin tip içinde konumlandırılabilir.

İtibarın toplumsal alana taşınması, esasında çok boyutlu bir üretimi de beraberinde getirmektedir. Bu üretim zaman, mekân, cinsiyet, kuşak değişkenlerine bağlı olarak farklı sosyal, kültürel, ekonomik ve sembolik sermaye içeriklerine, bitimsiz şekilde, anlam kazandırmaktadır. Bu üretim hâlihazırda verili sermaye alanları içinde dönüşmektedir. Ancak, itibar her ne kadar sermaye ve değişkenlere göre tanımlansa da toplumsal alanda sermaye kaynakları içinde ilk elden tanımlanamayan farklı bileşenlerin de varlığı söz konusudur. Söz gelimi, çok eşlilik, mafya babaları ile tanışıklık, çok erkek çocuk sahibi olmak, kız kaçırmak gibi faillerin öykündüğü ve bununla itibar arayışında olduğu bir gerçeklik görüntüsünden bahsedilebilir. Öykünülen bu durumlar, verili sermaye rezervlerinin toplum içindeki meşruiyetine, normalliğine, olağanlığına tezat oluşundan dolayı örtük/gizil işlemektedir. Dolayısıyla bu bileşenlere kısa zaman içinde vakıf olmak mümkün değildir. Bu tür örtük işleyen itibar fragmanlarını keşfetmek için söz konusu fragman mekanları deneyimlemek gerekir. İtibar, bu mekânsal kesitlerde nasıl ve neden üretiliyor, ne sıklıkla rutinleşiyor, diğer mikro gruplardan ne yönde farklılaşıyor, aksine pratik olarak itibarın üretiminde gruplar arasında bir benzerlik olup/olmadığı gibi sorular anlam bulmalıdır. Zira sosyolojik olarak grup yapılarının hala korunuyor olmasının bir nedeni olarak itibar kaynakları, grupları var 
eden enerji olarak değerlendirilebilir. Bu bağlamda bu çalışma, itibarın genel görüntüsünü yansıtmakta, birikimli bir şekilde farklı alanlara ve daha ilginç kaynaklara ulaşmak için bir ön veri olarak değerlendirilmesi gerekir.

\section{EXTENDED ABSTRACT}

The concept of reputation is basically used to express the image of corporate organizations before stakeholders. State institutions, companies that monopolize economic capital, aid organizations, universities and other educational institutions, NGOs and similar structures develop various strategies in order to seduce social consent. For example, a well-known brand organizes campaigns to gain or not lose customer satisfaction, tries to respond positively to customer demands, guarantees the quality of the product, acts in favour of the buyer in problem areas, guarantees various rights of employees, organizes social-environmental responsibility projects, and so it tries to construct / maintain brand image in the context of social consensus. The status of the institutions may change according to the positions they represent. In this context, the concept of reputation shortly expresses the trust of stakeholders in the institution. Although the corporate image comes to mind first when talking about reputation, the concept is used in different areas with similar meanings and connotations. Another area in which the value burden of reputation is functional is social interaction itself. In the day-to-day operation, actors establish relationships or distance from each other for certain reasons. Society is a meaningful whole with the existence of the phenomenon of interaction and the obstacles to it. Rather than everyone's contact with everyone, we can talk about a social relationship in the context of some actors' affiliation with some other actors. It is the sources of capital that hinder everyone's relationship with everyone and keep related individuals together for certain reasons. Devices like money, status, class, collective consciousness (asabiye), educational status, trust etc. devices embody interaction on the plane that enables and prevents it. These devices function as reputation objects and hence the interaction is reproduced according to the reputation hierarchy. Each hierarchical layer creates an interaction network in its own field. Individuals who have these resources attain a privileged, respected, distinguished, and respectable position by other actors of the society. While actors with similar resources establish relationships among themselves, individuals deprived of these resources are excluded from the network of relationships. Therefore, objects of reputation come to the fore with both creating and 
restrictive aspects of interaction. The reputation phenomenon, inspired by this sociological acceptance, has turned to micro fields through individual interaction rather than institutional structures in the study. This study has been concretized in the context of questions such as what are the sources of reputation in the social field, can reputation sources be differentiated according to certain variables, can reputable typologies be grouped within themselves, and if it is possible, which reasons are effective in this. In the theoretical part, the concept of reputation has been drawn from corporate reflections to individual reflections. A sociological analysis has been made in the context of the question of how reputation produces micro relations. The concept of reputation is generally interpreted in the axis of Bourdieu's discourses that condition the circulation of power and action, and the social existence strategies of Foucault's fragments of power.

The methodological part of the study was prepared on the basis of different variables such as age, gender, education level. In Konya, 850 people over the age of 14 were interviewed using quota sampling method in September-October 2019, and 19 survey data were excluded due to incomplete answers given to important questions. No ready-made scale was used in the study. The scale was first pre-tested with 50 people and took its final form after interviews with various social science experts. 40 statements were reduced to 30 statements according to pre-test and expert opinions. At the end of the study, the findings part was interpreted with 8 factor groups consisting of 23 expressions.

In the findings section, the data and the theoretical part of the study were analyzed together. The notion of trust came to the fore as the first factor, the theme with the highest burden of variance of the study. In the theoretical evaluation part, reputable figures were categorized as "distinguished" and "respected" according to their sources. Trust is included in the prestigious category with its symbolic capital. The third factor also has an image parallel to the first factor. It is because in this factor, the reflection of mediation on reputation as an outcome of responsibility is discussed. The second and sixth factors generally focused on the influence of religion on reputation. In the context of religious practices, the second factor is depicted as the negative production of reputation, and the sixth as the positive production of reputation. Both factors essentially functioned in a confirmatory / supportive nature to each other. These two factors illustrate Bourdieu's emphasis on the intended and strategic setting of the action. In the second factor, it exemplifies that the respectable type is seeking to move into the elite field with certain expectations of economic interest and the consequent damage to the reputation. The 
other factor has the opposite view. In the fourth and fifth factors, data on the production of reputation in the context of the gender variable were obtained. Male and female genders have gained reputation for different sources / reasons depending on the social reality to which they are attached. While different role expectations specific to women and men make reputation possible, there may be loss of reputation in role conflict. In general, the image of women has been deemed worthy of social reputation with various responsibilities, while men have been respected in the context of rights with masculine attitudes.

Seventh and Eighth factors, on the other hand, are mostly shaped by the social capital phenomenon. The seventh factor is the surname of individuals (such as -zade, -gil, -oğlu), being a member of well-known families and, accordingly, having a prestigious social capital. In the eighth factor, reputation has gained meaning with various symbolic and concrete indicators. It turns into a prestigious and useful capital tool with trailers that look at the society and tempt them, such as naming mosques and schools, hosting crowded organizations.

After revealing the reflections of reputation in the social field, the hidden sources of reputation will be revealed in the axis of more micro images of interaction. In this study, a general reputation map that can be expressed for almost every social fraction was formed. Along with this apparent and known aspect of reputation, it is necessary to depict the more subtle aspects of reputation that are in fact in circulation in micro groups. How groups produce the reserves they see as meaningful and reputable in their own dynamics, and how these reserves are interpreted according to other interaction spaces is also an important sociological data. Therefore, it is necessary to reflect the sociological projection to the phenomenon of reputation and to understand the social from a different perspective.

\section{KAYNAKÇA}

Aydemir, M. A. (2011). Sosyal Sermaye. Konya: Çizgi Kitabevi.

Bourdieu, P. (1986). Handbook of Theory and Research For The Sociology of Education. J. Richardson içinde, The Forms of Capital (s. 241-258). Westport: Greenwood Press.

Bourdieu, P. (2006). Pratik Nedenler. (H. U. Tanrı̈̈ver, Çev.) İstanbul: Hil Yayın.

Bourdieu, P,. \& Wacquant, J. D. (2016). Düşünümsel Bir Antropoloji için Cevaplar. (N. Ökten, Çev.) İstanbul: Illetişim Yayınları.

Cambridge Dictionary. (2020). 09 22, 2020 tarihinde Cambridge Dictionary: https://dictionary.cambridge.org/tr/sözlük/ingilizce-türkçe/reputation adresinden alındı 
Coleman, J. S. (2010). Beşeri Sermayenin Yaratımında Sosyal Sermaye. A. Z. Mehmet Murat Şahin içinde, Sosyal Sermaye Kuram Uygulama Eleştiri (s. 77-119). İstanbul: Değişim Yayınları.

Çokluk, Ö., Şekercioğlu, G., \& Büyüköztürk, Ş. (2012). Sosyal Bilimler lçin Çok Değişkenli Istatistik SPSS ve LISREL Uygulamaları. Ankara: Pegem Akademi.

Emler, N. (1990). A Social Psychology of Reputation . European Review of Social Psychology, 171-193.

Ermakoff, I. (2015). Rasyonel Seçim Teorisi Üstünlüğü Ele Geçirebilir. P. S. Gorski içinde, Bourdieu ve Tarihsel Analiz (Ö. Akkaya, Çev., s. 141-165). Ankara: Heretik.

Esen, E. (2011). Türkiye'deki ve Dünya'daki Itibar Ölçümlerinin Karşılaştırılması. Marmara Üniversitesi iktisadi ve Idari Bilimler Fakültesi Dergisi, 31(2), 289-306.

Fowler, B. (2019). Pierre Bourdieu: Ortodoks Olmayan Bir Marksist Mi? S. Susen, \& B. S. Turner içinde, Pierre Bourdieu'nun Mirası: Eleştirel Söylemler (A. K. Gülen, Çev., s. 57-83). Ankara: Phoenix Yayınevi.

Fukuyama, F. (2010). Sosyal Sermaye ve Sivil Toplum. A. Z. Mehmet Murat Şahin içinde, Sosyal Sermaye Kuram Uygulama Eleştiri (s. 140-170). İstanbul: Değişim Yayınları.

Goffman, E. (2020). Gündelik Yaşamda Benliğin Sunumu. (B. Cezar, Çev.) İstanbul: Metis Yayınları.

Gümüş, M., \& Öksöz, B. (2010). İtibarın Temel Taşı Olarak Kurumsal Iletişim: Kurumsal İtibar Sürecinde Illetişimin Rolü ve Önemi. Marmara Iletişim Dergisi(16), 111-124.

Güvenç, B. (2011). Insan ve Kültür. İstanbul: Boyut Yayıncılık.

Hinton, P. R., McMurray, I., \& Brownlow, C. (2014). SPSS Explained. NY: Routledge.

Hu, L.-t., \& Bentler, P. M. (1999). Cutoff criteria for fit indexes in covariance structure analysis: Conventional criteria versus new alternatives. Structural Equation Modeling: A Multidisciplinary Journal, 1(55), 1-55. doi:10.1080/10705519909540118

İnam, A. (2003). Herşeyin Başı Güven. F. Erdem içinde, Sosyal Bilimlerde Güven (s. 13-26). Ankara: Vadi Yayınları.

Joas, H., \& Knöbl, W. (2019). Yapısalcılık ve Pratiğin Kuramı Arasında: Pierre Bourdieu'nün Kültür Sosyolojisi. S. Susen, \& B. S. Turner içinde, Pierre Bourdieu'nün Mirası: Eleştirel Söylemler (A. K. Gülen, Çev., s. 25-56). Ankara: Phoenix Yayınevi.

Karatepe, S. (2008). Itibar Yönetimi: Halkla Ilişkilerde Güven Yaratma. Elektronik Sosyal Bilimler Dergisi, 77-97.

Kumar, R. (2011). Araştırma Yöntemi: Yeni Başlayanlar için Adım Adım Araştırma Rehberi. (Ö. Çokluk, G. Şekerçioğlu, \& H. Atak, Çev.) Ankara: Edge Akademi.

Mills, S. (2003). Söylem ve İdeoloji. B. Çoban, \& Z. Özarslan içinde, Söylem ve Ideoloji: Mitoloji, Din ve ideoloji (Z. Özarslan, Çev., s. 113-130). İstanbul: Su Yayınevi.

Murat Gümüş, B. Ö. (2010). İtibarın Temel Taşı Olarak Kurumsal Iletişim: Kurumsal İtibar Sürecinde Illetişimin Rolưve Önemi. Marmara Iletişim Dergisi(16), 111-124.

Neuman, W. L. (2017). Toplumsal Araştırma yöntemleri: Nitel ve Nicel Yaklaşımlar (Cilt 1). (S. Özge, Çev.) Ankara: Yayınodası. 
Özlem, D. (2017). Max Weber'de Bilim ve Sosyoloji. İstanbul: Notos Kitap.

Pira, A., \& Sohodol, Ç. (2008). Kriz Yönetimi : Halkla Ilişkiler Açısından Bir Değerlendirme. İstanbul: Illetişim Yayınları.

Sennet, R. (2011). Otorite. (K. Durand, Çev.) İstanbul: Ayrıntı Yayınları.

Smitds, A., \& Riel, C. B. (2001). The Impact of Employee Communıcation and Perceived External Prestige on Organizational Identication. In The Academy of Management Journal, 44(5), 1051 1062.

Swartz, D. (2013). Kültür ve Iktidar: Pierre Bourdieu'nün Sosyolojisi. (E. Gen, Çev.) İstanbul: Illetişim Yayınları.

TDK. (2020, 07 22). Türk Dil Kurumu Sözlükleri. 03 01, 2021 tarihinde https://sozluk.gov.tr/ adresinden alındı

Ural, E. G. (2002). İtibar Yönetimi Değer Yaratan Bir Halkla Illişkiler Çalışması Olarak Itibar Yönetimi. istanbul Ticaret Üniversitesi Dergisi, 83-93.

Weber, M. (2018). Ekonomi ve Toplum. (L. Boyacı, Çev.) İstanbul: Yarın Yayınları.

Yarar, A. E. (2019). Online İtibar Yönetimi. Konya: Çizgi Kitabevi.

Yavuz, K. (2003). Din ve Güven. F. Erdem içinde, Sosyal Bilimlerde Güven (s. 27-52). Ankara: Vadi Yayınları. 